\title{
Seaweed farming in Africa: current status and future potential
}

\author{
Flower E. Msuya ${ }^{1} \mathbb{D} \cdot$ John Bolton ${ }^{2} \cdot$ Fred Pascal $^{3} \cdot$ Koushul Narrain $^{4} \cdot$ Betty Nyonje $^{5} \cdot$ Elizabeth J. Cottier-Cook $^{6}$
}

Received: 16 September 2021 / Revised and accepted: 14 December 2021 / Published online: 1 February 2022

(c) The Author(s) 2022

\begin{abstract}
Global demand for seaweed and its products has increased exponentially over the last 25 years. Equally, the continent of Africa and its offshore islands have considerable potential for seaweed production to contribute to world demand. Compared with China and the rest of Asia, Africa lags behind in seaweed production and utilisation. However, for red eucheumatoid seaweeds, Africa is the third-largest producer in the world, producing about 120,000 $\mathrm{t}(\mathrm{FW})$ annually. Details are provided for 13 African countries that are currently involved in seaweed farming and harvesting, commercially or experimentally, for export or domestic utilisation. Eucheuma spp. and Kappaphycus spp. in Tanzania represent $92 \%$ and in Madagascar 4.7\% of continental production, and Ulva spp. and Gracilaria spp. in South Africa represent 1.5\%. Over 2000 species of seaweed have been recorded in Africa, some of which are already successfully cultivated in other parts of the world. The environmental conditions across the continent range from warm, tropical waters to the cooler, nutrient-rich waters of the southwest, enabling the cultivation of seaweeds from the tropical, carrageenan-producing eucheumatoids to temperate kelp species. Seaweed aquaculture production in Africa, led predominantly by women, has improved the livelihoods of its coastal people. Challenges through disease and pest outbreaks, as a result of climate change, and the low prices paid to farmers are highlighted as major constraints on the development of this industry. Through scaling up and expanding current efforts in production and utilisation of seaweeds, Africa has the potential to join China and Southeast Asia as a global leader in producing, processing and consuming a wide variety of seaweeds.
\end{abstract}

Keywords Seaweeds $\cdot$ Cultivation $\cdot$ Production $\cdot$ Species diversity $\cdot$ Africa

\section{Introduction}

African coasts have a considerable diversity of seaweed species with many distinct biogeographical regions, each with their own seaweed-dominated communities in coastal seas (Bolton et al. 2003). These include temperate regions in both north and south, a wide variety of Mediterranean biota, two

Flower E. Msuya

fmsuya1@gmail.com

John Bolton

John.Bolton@uct.ac.za

Fred Pascal

fred@ocean-farmers.com

Koushul Narrain

k.narrain@mric.mu

Betty Nyonje

bnyonje@hotmail.com

Elizabeth J. Cottier-Cook

Elizabeth.Cottier-Cook@sams.ac.uk significant and distinct tropical regions with extreme diversity on eastern tropical coasts, and globally significant kelp forest ecosystems in the south (Bolton et al. 2003). Over 2200 seaweed species have been recorded in Africa, consisting of more than 1400 red, ca. 400 green and almost 400 brown algal species (as listed in Guiry and Guiry 2021). This is more than $20 \%$ of the global total of ca. 11,000 species

1 Deparment of Botany, University of Dar Es Salaam, University Road, P.O. Box 35060, Dar es Salaam, Tanzania

2 Department of Biological Sciences, University of Cape Town, Cape Town, South Africa

3 Ocean Farmers, 601 Toliara, Madagascar

4 Mauritius Research and Innovation Council, Cyber City, Mauritius

5 Ministry of Fisheries, Nairobi, Kenya

6 The Scottish Association of Marine Science, Oban, Argyll, UK 
(https://www.seaweed.ie/). These include many species or their close relatives, which are commercially harvested and/ or cultivated in other continents worldwide. The African continent offers vast offshore, coastal and land resources suitable for seaweed cultivation, particularly in regions which are pollution-free and can offer a market advantage. Many African countries, however, have not exploited this potential to date. The cultivation of seaweeds, though has been shown to enhance livelihoods, provide employment and increase the gross domestic product in many other seaweed-producing nations (Valderrama et al. 2015). In Africa, seaweed farming varies between countries, from well-established, in the case of Tanzania (Msuya et al. 2014), to earlystage, with new farms granted licences only recently (e.g. Namibia). Some countries, for example Tanzania and Kenya, recognised the economic potential of seaweed in the 1930s, when it was collected from the wild and exported to Europe (Mshigeni 1973; Msuya et al. 2014; Bolton et al. 2016). Unfortunately, tough competition with Asia and low-quality seaweeds led to the collapse of this industry in the 1970s (Mshigeni 1992; Msuya 2013a; Msuya et al. 2014). There is still some export of dried kelp, however, from South African kelp forests (Rothman et al. 2020). In Namibia, the importance of seaweed production has been recognised since the 1980s, when seaweeds were harvested during the 1980s and 1990s and used to produce the gel agar (Molloy and Bolton 1995; Molloy 1998) and trial farming was done in the 1990s (Dawes 1995). Several other African countries, recognising the potential of cultivated seaweeds re-initiated production as early as 1989 in Tanzania (Msuya 2010, 2020; Msuya and Hurtado 2017), and Mozambique, Madagascar, Kenya and South Africa, amongst others, have developed their industries over the last two decades (Wakibia et al. 2006, 2011; Msuya et al. 2014).

The predominant seaweed species currently farmed around the African coastline are the red seaweeds Eucheuma spp. and Kappaphycus spp. with a production of 110,000-130,000 t (FW) annually (combining production in Tanzania, Madagascar and Kenya-see separate sections below). Gracilaria spp. and Ulva spp. are also farmed, but in smaller quantities (Anderson et al. 2001; Bolton et al. 2009; Bongani et al. 2013; Amosu et al. 2016). Global demand, however, for food, bio-materials and nature-based solutions to restore degraded environments and capture $\mathrm{CO}_{2}$, involving seaweeds, has risen exponentially in the last 20 years (Krause-Jensen et al. 2018; Filbee-Dexter and Wernberg 2020; Cottier-Cook et al. 2021). The African continent offers vast resources to address these demands. For example, Namibia is at the forefront of developing large-scale, offshore seaweed cultivation development, focusing on the giant kelp, Macrocystis pyrifera, with the eventual aim of producing over 70,000 $t$ annually by 2030 (Kelp Blue, 2020-unpublished).
The aim of this review paper is to present the current status of African seaweed production (including a comparison with the global situation) and provide an overview of the seaweed species farmed and collected from the wild, and their valorisation across the continent, whilst highlighting key challenges and providing recommendations on how the growth of a sustainable African seaweed aquaculture industry can be achieved.

\section{Global status of seaweed cultivation in Africa}

\section{Status of seaweed cultivation in Africa}

Africa is a continent of great potential for seaweed farming. It is the world's second-largest continent, with over $55 \%$ of its countries or territories bordering one of the four seas, which surround it. The continent encompasses a wide array of climatic zones from the cool northern and southern temperate environments to the warm tropical waters near the equator. The native seaweeds range from dense kelp forests, dominated by Ecklonia maxima and Laminaria pallida in the cool southern waters in Southern Africa, to the carrageenanproducing warm water red algal species, such as Kappaphycus spp. and Eucheuma spp. in the warm, tropical waters of Tanzania.

In terms of global production, the African continent ranks in second place for aquatic plant production (tonnes), producing $112,815 \mathrm{t}(\mathrm{FW})$, yet this is only a fraction of the 32.2 million tonnes produced by Asia in 2018 (FAO 2020). Excluding Asia, Africa has significantly out-performed other continents since 2002, particularly with the production of the carrageen-producing red algae in Zanzibar, Tanzania (Fig. 1).

In Africa, current aquaculture production in the marine environment is dominated by aquatic plant production, such as the red algae Eucheuma sp., Kappaphycus spp., the agarproducing Gracilaria spp. and the green sea lettuce Ulva spp. (FAO 2020). Arthrospira platensis, a freshwater cyanobacterium, commonly known as 'Spirulina', however, also accounts for a small proportion of the aquatic plant production, with Burkina Faso, Central African Republic, Chad, Senegal and Tunisia producing $281 \mathrm{t}$ (wet weight) in 2018 (FAO 2020).

\section{Global perspective}

Aquatic plant production in the marine environment, including seaweeds, was first recorded in 1989 by the FAO and the production has grown significantly over the last 30 years. A peak in production of 196,570 $t$ was recorded in 2015, although a $43 \%$ reduction in production was observed 
Fig. 1 Continental aquatic plant production (excluding Asia) from 1950 to 2018 (FAO 2020)
250000

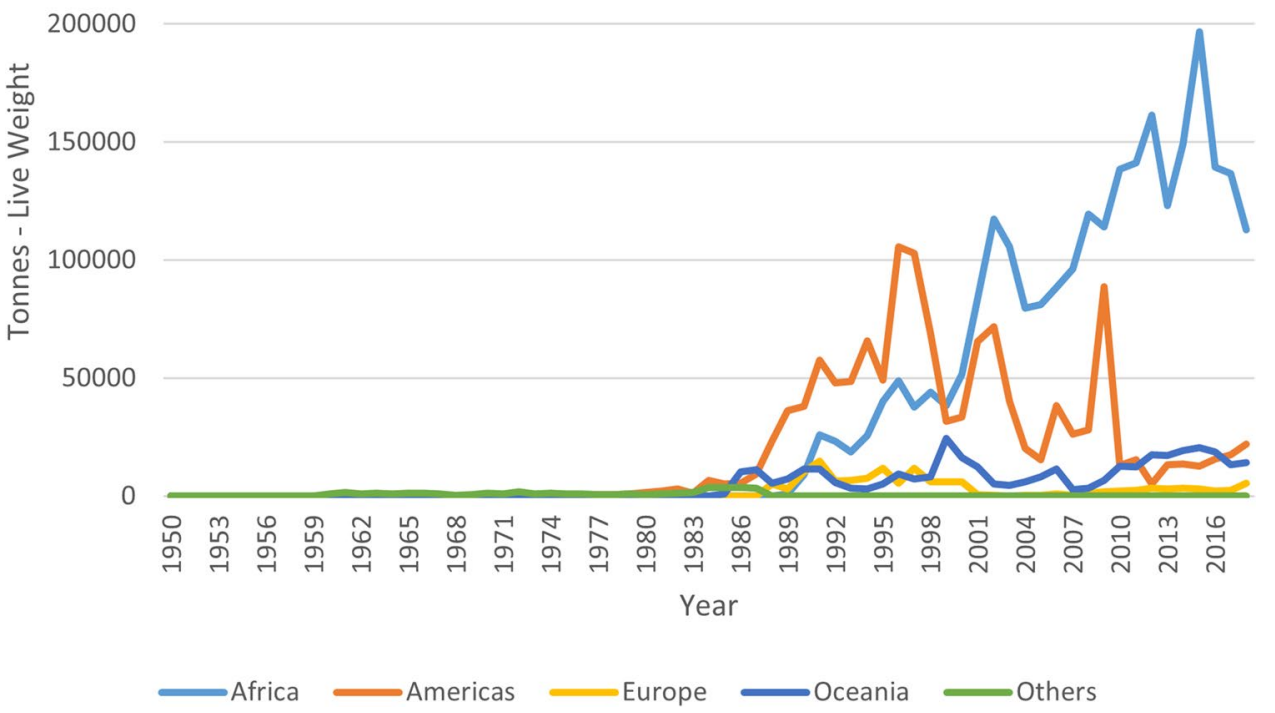

between 2015 and 2018, as a consequence of climateinduced outbreaks of seaweed-specific pest and diseases, together with other economic-related impacts on price (Rusekwa et al. 2020; Sánchez-Velásquez et al. 2021).

The production of marine aquatic plants in Africa is currently concentrated in Zanzibar (Tanzania) (102,960 t FW), followed by Madagascar (53,370 t) and South Africa (16,870 t) in 2018. Other countries, however, including Kenya, Morocco, Mozambique, Namibia and Senegal, are all still either currently producing or have previously produced seaweeds in the past few years (FAO 2020, Fig. 2).

With global seaweed production expanding exponentially over the last few decades and growing international demand for this product, particularly from countries with no traditional consumption or use of seaweeds (Cottier-Cook et al. 2016), Africa has significant coastal resources available to increase its seaweed production and to capitalise on this growing demand. Climate change and low gate prices are just a couple of the challenges faced by the industry (Cottier-Cook et al. 2016), but seaweed farmers in Tanzania have shown how the industry can develop over a relatively short period of time, to become one of the leading producers outside Asia (Msuya et al. 2014).

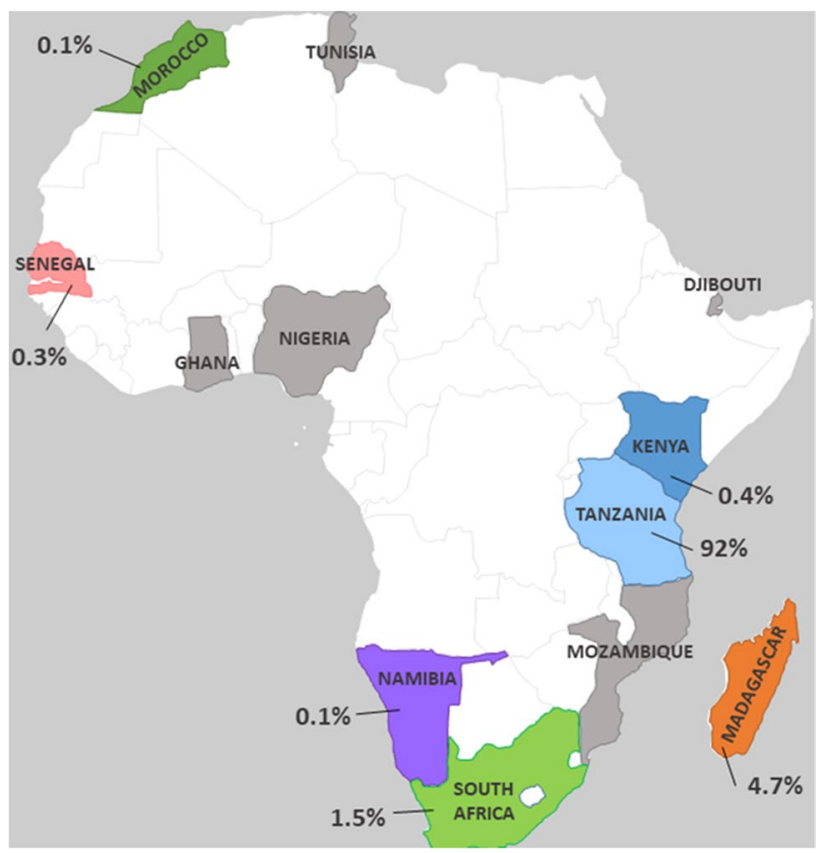

Fig. 2 African countries with either current or previously reported marine aquatic plant production 1989-2018. Proportion of seaweed production is shown for 2018 (FAO 2020) 


\section{Seaweed farming in Africa}

\section{Eastern Africa}

Tanzania

Species richness and diversity Approximately 428 seaweed species of Rhodophyta, Chlorophyta and Phaeophyceae have been recorded in Tanzania (Msuya 2020). Amongst these, only a relatively small number of species are used for commercial cultivation, including the red seaweeds Eucheuma spp. and Kappaphycus spp. Three species of Eucheuma are found growing naturally in Tanzania, E. denticulatum (commercial name 'Spinosum'), E. platycladum and E. okamurai, and one species of Kappaphycus, K. striatus (commercial name 'Cottonii') (Mshigeni and Jahn 1995; Msuya 2020). The cultivation potential of Eucheuma spp. and Kappaphycus spp. was studied in the 1970s-1980s and began in earnest in the late 1980s. The potential for cultivating Gracilaria spp., another genus of the red alga, has also been explored through growth (Msuya and Neori 2002) and agar composition studies (Buriyo and Kivaisi 2003).

Production volumes and prices The Tanzanian seaweed industry employs about 30,000 farmers, most of whom are women. The main species farmed are the eucheumatoid species $E$. denticulatum, $K$. striatus and $K$. alvarezii, varieties of which were imported from the Philippines in 1989. Whereas production of E. denticulatum is above 100,000 $\mathrm{t}(\mathrm{FW})$, the production from the genus Kappaphycus is less than 10,000 $\mathrm{t}$ (FW). Seaweed production in Tanzania has increased rapidly since the start of the industry in 1989, particularly in Zanzibar, which is comprised of two islands, Pemba and Unguja. Production increased from $8080 \mathrm{t}$ in 1989 to the current $107,000 \mathrm{t}$, with a maximum production of $176,000 \mathrm{t}$ recorded in 2016. Since 2016, however, production of Kappaphycus has declined significantly as a result of disease, such as ice-ice disease syndrome, and epiphyte outbreaks that have been exacerbated by increasing surface seawater temperatures linked to climate change (Msuya 2011a; Msuya and Porter 2014; Largo et al. 2020).

Prices for cultivated seaweeds in Tanzania vary depending on whether the crop is sold as "seedlings" (fresh weight) or as a dried, bleached or unbleached product, which is subsequently used for the industrial extraction of carrageenan. Fresh, live Kappaphycus spp. and Eucheuma spp.) sold as seedlings or for making seaweed products, currently sell at 500-1000 TZS (US\$ 0.2-0.4 kg-1) (F. Msuya, Pers. Obs., 2021 market price). The current price of dried, unbleached seaweed is 600-800 TZS (equivalent to US\$ $0.26-0.35 \mathrm{~kg}^{-1}$ ), whereas bleached seaweed sells between
3000 and 10,000 TZS (US\$ 1.30-4.35 kg-1) (F. Msuya, Pers. Obs.). Prices of dried seaweed, however, have recently increased to 1800 TZS ( US\$ $0.8 \mathrm{~kg}^{-1}$ ) for Kappaphycus spp. in Zanzibar, following the intervention of the government (through its State Trading Corporation), to purchase seaweed from farmers as a step towards establishing a processing plant on Pemba Island for the production of carrageenan and other products (Msuya 2020).

Production methods The main technique of farming seaweeds in Tanzania is the off-bottom (peg and line), which is typically used in shallow waters ( $<1 \mathrm{~m}$ at low tides). In this technique, seaweed seedlings of about 100-200 $\mathrm{g}$ are tied to nylon ropes (lines) using thinner ropes of the same material, known as "tie-tie". The main lines are then stretched between two wooden pegs, which are secured firmly into the seabed. The lengths of the lines vary depending on the site (e.g. whether the region is subjected to strong waves) or the physical strength of the farmer, in that male farmers typically use longer lines compared with the female farmers. The distance between the seedlings is approximately 20-30 cm. This technique is "easy to use", as it allows the farmers to work during the period of low tide (Msuya 2011b). Other techniques have been researched and some piloted, including the floating line system (Msuya 2013a; Valderrama et al. 2015), bamboo rafts (Msuya 2011a, 2011b, 2020), net bags (Msuya 2011a,b; 2017; 2020) and tubular nets (Msuya 2015-unpublished; Msuya 2017, 2020; Brugere et al. 2020). Bamboo rafts and tubular nets are also used in other countries in Southeast Asia and South America (Brazil) (Góes and Reis 2011, 2012; Reis et al. 2015). Harvesting typically occurs after a growth period of 45 days and a proportion of the crop is retained for the next growth period (i.e. through clonal propagation, Msuya 2013a). If for some reason, additional seedlings are required, "neighbouring farmers" typically share seedlings or, if the crop has been lost or affected by a pest or disease outbreak, then the export companies generally supply the seedlings (Msuya 2013a). Other sources of seedlings, however, include the private sector (e.g. NGOs, initiatives such as the Zanzibar Seaweed Cluster) and the government, through various projects and programmes, such as the Marine and Coastal Environment Management (MACEMP) Project (Department of Marine Resources, Zanzibar).

Challenges to sustainable seaweed production in Tanzania Seaweed diseases and pests have become increasingly prominent in the last 10 years threatening the future of the Tanzanian seaweed industry. The occurrence and perseverance of diseases (mostly ice-ice disease syndrome) and epiphytism from red filamentous algae (e.g. Melanothamnus, formally known as Polysiphonia/Neosiphonia), particularly on the higher value Kappaphycus spp., make it impossible 
for farmers in most farming areas in Tanzania to grow this species (Hayashi et al., 2010; Msuya 2011a, 2011b; Msuya and Porter 2014; Largo et al. 2020). The production of Kappaphycus spp., therefore, has remained at less than 10,000 t (FW) annually since 2002 (Msuya 2020). In the last 5 years, however, even the lower value and hardier E. denticulatum has been affected by disease and pests during the hot season, where the surface seawater temperatures have been recorded at 33-38 ${ }^{\circ} \mathrm{C}$ (Msuya and Porter 2014; Largo et al. 2020; Msuya 2020). During this season, farmers are now having to change their practices, by halting their seaweed production until the rainy season, when temperatures fall below $30{ }^{\circ} \mathrm{C}$ (Largo et al. 2020). Seaweed biosecurity policies are lacking in Tanzania and responses to disease and pest outbreaks are not well coordinated and control measures, in most cases, are not practised by farmers (Rusekwa et al. 2020). However, the government, private sector and other stakeholders have conducted training programmes in recent years, to inform farmers about how to manage their farms, particularly in relation to minimising the risk of pest and disease outbreaks (Rusekwa et al. 2020). In particular, the introduction of seedlings has been shown to be a high-risk pathway for the transfer of pests and diseases onto the farm (Kambey et al., 2020). Quarantine measures for these seedlings, however, are lacking in Tanzania and it is possible that some stakeholders may import them into the country without checks (Campbell et al. 2020; Rusekwa et al. 2020).

Several studies have shown that without intervention by the government through research and other responsible stakeholders, the future of the Tanzanian seaweed industry could be at stake (Msuya and Porter 2014; Largo et al. 2020). Measures to support the sustainable development of this important industry include technological developments for farming and value addition, support to the farmers for marketing their dried seaweeds and associated products, implementation of research results and having a specific seaweed biosecurity policy (Campbell et al. 2020; Msuya 2020; Rusekwa et al. 2020).

Opportunities for the seaweed industry in Tanzania Seaweed value addition in Tanzania started in 2006, when the Zanzibar Seaweed Cluster Initiative (ZSCI-www.seaweedclu ster.or.tz) was established. This initiative has focused on the production of value-added products, such as cosmetics (e.g. soap, lotions and shampoo) and food (e.g. juice, jam, crackers and noodles) from fresh and dried seaweed. The ZSCI is predominantly composed of small-scale farmers and processors, with between 57 and $100 \%$ of total processors being female across the country (Msuya and Hurtado 2017). The ZSCI originally began with one group of 21 farmers, which has now grown to over 25 groups with more than 400 members. This member now produces over 50 products, which are sold countrywide (Msuya 2006; Msuya and Hurtado
2017). Seaweed value addition uses about $1 \%$ of the volume of seaweed produced in Tanzania, whilst the majority of the seaweed is still sold to overseas buyers, as unprocessed raw material for industrial purposes (i.e. kappa and iota carrageenan extraction). The market for the value-added products is mainly found in tourist-related destinations, exhibitions, trade fairs and, to a smaller extent, individual purchasers (Msuya and Hurtado 2017). The government of Zanzibar, however, has recognised the added- value of processing the raw materials in the country and is supporting the development of an indigenous seaweed processing industry to produce its own supply of carrageenans for internal use and export. This effort is one of the outcomes from several governmental and ministerial committees that were tasked to advise the government of Zanzibar on how it could advance its seaweed industry. Key recommendations from these committees included that the government should be engaged in seaweed value addition, to raise the seaweed price for farmers and that a processing industry should be established, which would motivate the farmers to increase production, as they were guaranteed a higher price for their crop compared with the price currently offered by the exporters.

\section{Madagascar}

Species richness and diversity Madagascar, the world's fourth-largest island, has a long coastline of $5603 \mathrm{~km}$ and has a high diversity of species (Rahelivao et al. 2015; Vieira et al. 2021). Mattio et al. (2015) mentioned a search of Algaebase giving a total of 329 species for this country. Considerable collections were made of Madagascan seaweeds in the 'Altimo Vitae' expeditions (2010-2013), and many new records were added from these studies. Only three seaweeds, Gelidium madagascariense, E. denticulatum and K. striatus, have been exploited for economic purposes, including the production of agar and carrageenan (Mollion 2020). Other species including Portieria hornemannii, Grateloupia sp., Gracilaria corticata, Halymenia sp. and Laurencia complanata have been investigated for their bioactive compounds and recommended as sources of natural products (Rahelivao et al. 2015).

Production volumes and prices The economic importance of seaweeds in Madagascar dates back to 1966, when a mixture of unidentified species was harvested from the wild and exported from the Fort Dauphin area in "un-organised" trade (Mollion et al. 1996). This trade became more organised in the mid-1980s to the early 1990s, when $3000 \mathrm{t}$ of Gelidium madagascariense and $5000 \mathrm{t}$ of $E$. denticulatum and $K$. striatus combined were harvested in Tulear and Fort Dauphin and exported to Japan and France (Mollion et al. 1996; Mollion 2020). The trade continued until 2000, when it was halted due to inadequate export volumes, leading to 
Fig. 3 Exportation of aquaculture-produced seaweed (DW) from Madagascar, 2000-2020. Source: seaweed farming companies, Madagascar; Global Trade Atlas

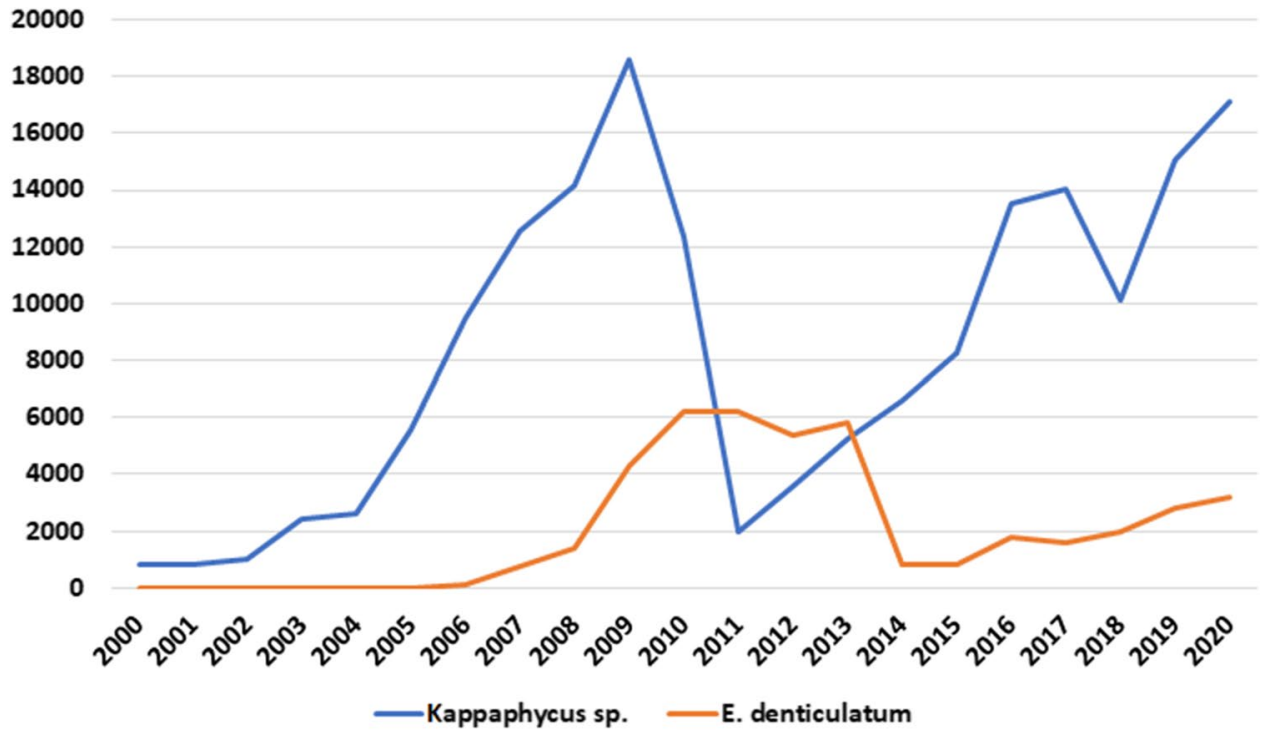

a loss of interest by the importing companies. It was also reported that the volume of harvested seaweed declined over time, with only $150 \mathrm{~kg}(\mathrm{FW})$ of seaweed collected annually before 2000 to $80 \mathrm{~kg}$ after 2000 (Mollion 2020).

Cultivation of $E$. denticulatum and $K$. striatus started with initial experiments using native varieties in 1990 and by 1998; the production had increased significantly (Mollion 2020). However, as in many other countries cultivating eucheumatoids, Madagascar imported varieties of these two species to boost production. Currently, Madagascar is the second-largest producer of seaweeds in Africa (FAO 2020). The prices paid to the farmers were US\$ $0.15 \mathrm{~kg}^{-1}$ of dry seaweed between 2016 and 2017 (Mollion 2020). Several commercial strains of $K$. alvarezii, $K$. striatus and $E$. denticulatum were introduced from Zanzibar, Tanzania. These strains having originated in Southeast Asia in the 1990s and 2000s and commercial initiatives to date have been concentrated in the northeast and southwest of the country (Msuya et al. 2014; Mollion 2020). All of the seaweeds are exported as unprocessed biomass directly to the main processors in America, Europe or Asia (Mollion 2020). Overall, the export tonnage of Kappaphycus increased from 800 to $17,000 \mathrm{t}(\mathrm{FW})$ between 2000 and 2020 and $E$. denticulatum from $90 \mathrm{t}$ in 2006 to $3000 \mathrm{t}$ (FW) in 2020 (Fig. 3).

Production methods In the farming regions, the cultivation techniques encompass various off-bottom and long-line systems, with tubular net farming replacing traditional farming ropes, where water turbidity allows (tubular nets are unsuitable in turbid water, as sediments get trapped in the nets and prevent optimal seaweed growth, F. Pascal, Pers. Obs.).

Challenges to sustainable seaweed production in Madagascar Despite disease and pest outbreaks, which led to the almost total collapse of the industry in the late 2000s (Msuya et al. 2014), new producers decided to pursue the farming efforts in both regions. Pests, such as epiphytes and diseases causing ice-ice disease syndrome associated with seasonal temperature variations, however, remain the main challenges to production (Mollion 2020). In the northeast, Nosy Ankao island is farmed by IBIS Madagascar and became the main Kappaphycus spp. production area between 2000 and 2011. Production collapsed (Fig. 3), however, following epiphyte outbreaks, which began in 2009 and were not possible to control. Consequently, farming of $E$. denticulatum replaced Kappaphycus spp. in areas where pathogen outbreaks have been too intense to maintain the farming of Kappaphycus spp. As a result, both the farmers and farming company became discouraged and many have shifted their focus to other activities. In 2020, E. denticulatum production, however, was estimated at $3000 \mathrm{t}(\mathrm{FW})$ and Kappaphycus spp. continued to be farmed in Cap Est and Sainte Marie Island lagoons, reaching an estimated production of $3,000 \mathrm{t}(\mathrm{FW})$.

Opportunities for the seaweed industry in Madagascar In general, the business model in Madagascar for seaweed farming is company-based, although in some instances there is the inclusion of independent smallholder farmers. In the southwest, though, a hybrid strategy is employed, named "contractual community-based farming", which has been developed by the leading farming company in the area: Ocean Farmers. This strategy was implemented in 2011 and the main objective of this hybrid approach was to ensure environmental, social and economic sustainability of seaweed farming in the area through effective management of production. This approach has led to a gradual increase in production of $K$. alvarezii (tambalang var.) reaching 15,300 $\mathrm{t}(\mathrm{FW})$ in 2020 (F. Pascal, Pers. Obs.). This increase was 
achieved despite the requirement to closely manage epiphyte outbreaks, which have reoccurred annually since 2016 across all areas and led to a temporary drop in production in 2018 (Fig. 4). Bioclimatic risks and pest and disease outbreaks, though, are being addressed through the close supervision of the phyconomic aspects by the farming company. For example, farming techniques and strategies are site-specific, the type and quantity of farming material are carefully selected and managed, the crop is regularly surveyed for pest and disease, control measures are in place if an outbreak occurs and concerted spatial management plans have been created. In addition, farmers receive training in farming techniques and biosecurity from the private sector. These activities are ensured through formal contracting and incentive mechanisms (e.g. rewarding best-performing farmers) with more than 1600 smallholder farmers located across 42 rural communities, all supervised by seaweed technicians trained and employed by Ocean Farmers. The hybrid model also relies on the promotion of relational governance, through the inclusion of conservation International Non-Governmental Organisations (INGOs), Locally Managed Marine Areas (LMMAs) community organisations, education and research institutes, financial partners and the administration (F. Pascal, Pers. Obs.). A coordination forum- the "south-west sustainable aquaculture platform", also including sea cucumber farming operators - was established in 2015 and meets every quarter. Ecosystem-based projects, such as coral farming (as restoration) and seagrass protection, are also implemented around the seaweed farms, under the assumption that a healthy and diverse ecosystem will lead to improved farm sustainability, including faster growth rates and crops that are less vulnerable to epiphytes, diseases and climate change (F. Pascal, Pers. Obs.). However, this still has to be validated by scientific assessments.

\section{Kenya}

Species richness and diversity of seaweeds Approximately 400 seaweed species have been recorded in the waters off the Kenyan coast, which stretches $\sim 640 \mathrm{~km}$ (Yarish and Wamukoya 1990; Oyieke 1998; Bolton et al. 2007). The most dominant of these species are the red algae that represent $55 \%$ of the recorded seaweeds, followed by the green $(30 \%)$ and brown algae $(15 \%)$.

Efforts to assess the economic importance of seaweeds in Kenya started in the 1980s. A survey conducted between 1987 and 1989 showed that Kenya had many potentially important seaweeds in its coastal zone (Yarish and Wamukoya 1990). These included several phycocolloid-bearing species, including the carrageenophytes Eucheuma spp., Kappaphycus spp. and Hypnea spp.; the agarophytes Gracilaria spp. and Gelidium spp.; and the alginophytes Sargassum spp., Turbinaria spp. and Cystoseira spp. (Yarish and
Wamukoya 1990). These assessments also revealed that the major sources of carrageenan in Kenya would be Eucheuma spp., Kappaphycus spp., Halymenia spp. and Hypnea spp., all of which have high gel yields (Mshigeni and Semesi 1977; Semesi 1979). The survey reported that large populations of Eucheuma, Kappaphycus and Hypnea were distributed along the Kenyan coast and recommended their cultivation to increase the crop production for economic purposes (Yarish and Wamukoya 1990). This study also recommended the development of seaweed farming in the Shimoni area in southern Kenya, owing to the abundance of the commercially important species and the suitability of the substratum and physical conditions (e.g. salinity, light and temperature). Other studies on the commercial potential of Kenyan seaweeds studied the lipid composition of five seaweed species, Hypnea musciformis, E. denticulatum, Laurencia intermedia, Sargassum oligocystum and Ulva fasciata, as possible fat alternatives in the production of chicken sausages (Muraguri et al. 2015). Mwalugha et al. (2015) also studied the chemical composition of thirty-four species (12 Chlorophyta, 13 Phaeophyceae and 9 Rhodophyta) in three areas of Kenya and recommended these species as sources of food for human and animal nutrition.

Production volumes and prices The technical feasibility of farming seaweed was subsequently established by the Kenyan Marine and Fisheries Research Institute in the mid1990s and early 2000s (Wakibia et al. 2006, 2011). The seedlings for the experimental trials for the two farmed species, E. denticulatum and Kappaphycus alvarezii, were obtained from Zanzibar, but had been originally imported from the Philippines (Wakibia et al. 2011). The first commercial farms were established in 2010 in Kibuyuni, southern Kenya by 20 farmers after demonstration farms had been successfully established in the same area in late 2008 to 2009. These demonstration farms provided the seedlings for E. denticulatum and built the capacity of the community, who were identified as pioneers for seaweed farming in the country (Nyonje et al. 2013-unpublished). According to Mirera et al. (2020), the effort increased seaweed production from less than 10t (FW) in 2008 to above 450t (FW) in 2017.

To date, there are 416 active seaweed farmers from 10 villages in Kwale County, southern Kenya, a significant increase from the 90 farmers actively farming in 2010 (Nyonje et al. 2013-unpubl.; Nyonje 2020a-unpubl.; Nyonje 2020b-unpubl.) and there are prospects for several other communities to join in the farming venture. Currently, $90 \%$ of the farmers are women (Nyonje et al. 2017-unpubl.; Odhiambo et al. 2020) and the main species cultivated is $E$. denticulatum (Odhiambo et al. 2020).

The mean production volumes in Kenya have increased from 500t $(\mathrm{FW})$ in 2013 to approximately $1000 \mathrm{t}(\mathrm{FW})$ in 2020 (Nyonje, Pers. Obs.), but remains below full capacity 
(Nyonje, Pers. Obs.). Extreme weather conditions, with very high seawater temperatures during the Northeast monsoon season and high rainfall during the Southeast monsoon in 2018-2019, led to massive die-offs, as a result of significant pathogen outbreaks (Nyonje, Pers. Obs.).

The farms are typically characterized by smallholder farmers, who are supported with farming materials and training from the National and County governments, NGOs and investors interested in buying the seaweeds (Nyonje, 2020-unpubl.). The main buyer of the Kenyan seaweed is the C-Weed Corporation (Kenya) Limited- https://cweed. com/, a locally registered company, whose parent company is one of the largest seaweed buyers in the region, with over 30 years of trading in seaweeds in Zanzibar (Nyonje, Pers. Obs.). The company aims to work with over 2000 farmers to ensure commercial viability (Nyonje, Pers. Obs.). The double-loop method of attaching the seedlings to the cultivation lines to optimise production for their export market has been recently introduced by the company and it has technicians training the farmers in this new method (Nyonje, Pers. Obs.). Once harvested, the majority of the seaweed is directly exported to France, Spain or the USA (Nyonje, Pers. Obs.). Currently, the farm gate price of the dry seaweed is about $0.25 \mathrm{USD} \mathrm{kg}^{-1}$.

Production methods The main method of cultivation is the off-bottom monoline technique, which is applied in shallow water areas in the nearshore/intertidal zone, allowing the lines to be exposed during the spring low tide. The seaweeds are harvested after three spring tides, having grown for about 6 weeks or 45 days (Msuya et al. 2012; Msuya 2013b). Other cultivation methods, such as the raft method, broadcasting method and net methods, have also been tested; however, the economic feasibility of these methods have not been evaluated, and thus, these have not been scaled for commercial farm trials (Kimathi et al. 2018, Ntabo, 2020-unpubl.).

Opportunities for the seaweed industry in Kenya In 2016, an FAO project encouraged seaweed farmers in Kibuyuni to manufacture seaweed soap, with training in the production of seaweed soap, body cream and foods such as jam, juice and salad (Msuya 2016-unpubl.). FAO also trained the farmers on best business management practices, such as agronomy, harvesting, handling and marketing (Msuya 2015-unpubl.; 2016-unpubl.). The seaweed farmers' group also worked, with the Kenyan Industrial Research and Development Institute and other agencies, to develop various other cosmetic and food products, minimise post-harvest losses and introduce other aspects of best management practices (Nyonje et al. 2017-unpubl.). With the growing interest in seaweed farming from a range of stakeholders and with the socio-economic benefits for the local communities having been demonstrated (Mirera et al. 2020; Odhiambo et al.
2020), the government of Kenya identified this industry as one of the priority interventions under the Blue Economy Initiative (Blue Economy Committee Report 2016-unpubl.). Subsequently, the government is planning to map the entire Kenyan coastline for suitable sites for seaweed farming and to develop the industry value chain (Blue Economy Committee Report, 2016-unpubl.). The relatively low initial capital investment and rapid returns make the scalability of seaweed farming more feasible than other capital-intensive interventions in the country (Blue Economy Committee Report, 2016-unpubl.; Nyonje, 2020-unpubl.). For sustainability, farmers are also being organised into economically viable entities, such as cooperatives and other community-based organisations. The overall long-term strategy for building resilience amongst the farmers is targeted to incorporate the introduction of Integrated Multi-Trophic Aquaculture, for co-culture of seaweed with finfish and sea cucumbers (Blue Economy Committee Report, 2016-unpubl.).

Considering the challenges currently experienced at some of the farming sites, research into better agronomy, development of climate tolerant and disease resistant strains for this region and diversification of farmed species are aspects of the strategy that still need urgent attention (Blue Economy Committee Report, 2016-unpubl.). Experimental studies have been undertaken for Gracilaria spp. to be considered for agar production (Ollando et al. 2019), whilst other studies have explored the farming of edible seaweeds, such as Caulerpa racemosa (Mwalugha et al. 2015; Nyonje, Pers. Obs.) and those that can be used in animal feed (Muraguri et al. 2015; Arori et al. 2019). The prospects for developing a fully fledged seaweed industry in Kenya are, therefore, promising and seaweed presents a potential post-COVID blue recovery opportunity for coastal communities (Northrop et al. 2020). Mobilisation of communities in suitable sites for cultivation, capacity building and some targeted investment though will be required from both the public and private sector to realize this ambition.

\section{Mozambique}

Species richness and diversity of seaweeds Mozambique, as is the case for other coastal Eastern African countries, has a rich diversity of seaweeds and it has one of the longest coastlines in Africa reaching ca. $2800 \mathrm{~km}$ (Carvalho and Bandeira 2003). However, studies on available seaweed resources are scarce (Carvalho and Bandeira 2003). Some of the early recorded work is that of Critchley et al. (1997), who reported 205 species comprising of 64 Chlorophyta, 23 Phaeophyceae and 118 Rhodophyta in Inhaca Island, southern Mozambique. Equally, another study in the Quirimbas Archipelago, northern Mozambique found 101 taxa comprising of 38 Chlorophyta, 25 Phaeophyceae and 38 Rhodophyta 
and reported that 27 of them were new records to the country (Carvalho and Bandeira 2003). Fifty-three species (24 species of Chlorophyta, 18 Phaeophyceae and 12 Rhodophyta species) were subsequently reported in Nampula Province, northern Mozambique (Massingue and Bandeira 2005). In Mozambique, Eucheuma spp. was introduced in Murrebue Village (1998), Pemba (2002) and Nampula (2006) with the assistance of FMC Health and Nutrition (Bryceson and Massinga, 2002). This venture involved 2000 farmers, of which $80 \%$ were women. The production in 2003 was 500 $\mathrm{t}$ (FW), and by 2004, this had reduced to $140 \mathrm{t}$ (FW). All farming ended by 2006 due to inconsistent production and logistical challenges (Ribeiro 2007).

Production volumes and prices The first reports of seaweed cultivation in Mozambique were during 1998, when Eucheuma spp. was introduced in Murrebue village by FMC Health and Nutrition (Bryceson and Massinga, 2002). Commercial production started in the early 2000s in Pemba, located in the north, and in Nampula by 2006 (Msuya et al. 2014; Omar 2009-unpubl.) using Eucheuma spp. and Kappaphycus spp. seed imported from Zanzibar, Tanzania. In 2002, a production of $1570 \mathrm{t}(\mathrm{FW})$ value at US\$ 31,000 was reported by FAO (undated). By 2003, production of $5230 \mathrm{t}$ (FW) valued at US\$105,000 of Kappaphycus and Eucheuma was reported, involving 2000 farmers (Msuya et al. 2014; Omar 2009-unpubl.; FAO-(undated). However, the production significantly declined to 230 by 2009 , with only 143 farmers remaining in the industry (Msuya and Massinga 2018-unpubl.). Approximately $80 \%$ of the seaweed farmers in Mozambique, as in other eastern African countries, are women who earn more than US\$ 60 per month (FAOundated). The seaweeds from Mozambique were exported to Asia and Europe.

Production methods Mozambique seaweeds are cultivated in shallow water areas using the off-bottom peg and line method (Msuya et al. 2014; Omar 2009-unpubl.; FAO (undated)). No other cultivation methods have been reported in Mozambique.

\section{Challenges to sustainable seaweed production in Mozam-} bique The seaweed industry in Mozambique faces the challenge of low seaweed production resulting in an inability to cope with the needs of buyers for the international markets. This was evidenced by the collapse of the industry in 2010, due to inconsistent quality and an unreliable supply of seaweed to the export market (Msuya et al. 2014; Omar 2009-unpubl.). The situation remains unchanged, but efforts are being made by the government and other stakeholders to revive the industry.

Opportunities for the seaweed industry in Mozambique The potential for seaweed cultivation in Mozambique was reported in 2011, with 10,591 ha identified as suitable for seaweed farming (Omar 2009-unpubl.). A feasibility study was also conducted to evaluate the technical and market viability of seaweed production in the Palma District, northern Mozambique (Anadarko, 2015-unpubl.; Msuya and Massinga, 2018-unpubl.). The study identified nine sites (villages) that were suitable for farming E. denticulatum and Kappaphycus spp. These were Salama, Nsemo, Kibunju, south of Nfunzi, Nfunzi proper, Maganja Velha and Mbawala. The farming of Gracilaria spp. was also recommended.

The government of Mozambique is now promoting the co-culture of seaweeds and bivalves (FAO-undated), as a viable opportunity to produce two products in the same area, increase food production and enhance the livelihoods of coastal communities involved in this practice. A seaweed farming and processing company, SELT MARINE Group, has also recently gained a 500-hectare concession from the Mozambique government to farm K. alvarezii and E. denticulatum in Nacala (Sepulveda-unpubl.- https://www.subma riner-network.eu/images/grass/Seaweed_farming_and_ industrial_processing.pdf) and to export the dried seaweed to its processing plant in Tunisia (see "Northern Africa"). The company is aiming to provide up to 1000 direct jobs by $2022 / 2023$ and is investing in training workshops and providing technical assistance for the farmers. The farmers cultivate the seaweed in shallow water using the long-line technique used in Tanzania (SELT Marine, https://www. submariner-network.eu/images/grass/Seaweed_farming_ and_industrial_processing.pdf).

\section{Djibouti}

Species richness and diversity of seaweeds The coast of Djibouti is rich in seaweeds of various species, but the evaluation of these seaweeds for possible utilisation is limited (Fourreh et al. 2019). IFAD (Social reporting Blog, 2014) reported that "On the beaches of Djibouti, phycocolloid rich seaweed can be found in abundance, neglected because their virtues are largely unknown" showing the richness of the coastal area of Djibouti in seaweed. Mshigeni (2012-unpubl.), who visited Djibouti in 2012, reported on the brown seaweeds, Sargassum spp., Turbinaria spp. and Hormophysa spp. cast upon the beach. These were defined by the author as potential sources of phycocolloid and could be exploited for economic and livelihood development in Djibouti. Fourreh et al. (2019) studied seven species of phaeophytes, including Cystoseira myrica, Padina pavonica, Sargassum fluitans, S. ilifolium. Sargassum sp., Turbinaria triquetra and T. turbinata for their natural products and recommended them as sources of antioxidants. 
Farming trials and challenges Trials for farming eucheumatoids were first conducted in Moucha Island in the Gulf of Tadjourah, Djibouti, in the late 1970s by Braud and Perez (1978), using seaweed imported from Indonesia. The trials were successful and the authors were keen to start commercial farming, but since they were French nations, they were required to leave Djibouti when the country gained its independence.

Opportunities for the development of the seaweed industry in Djibouti In 2012, Mshigeni (2012-unpubl.) once again recommended Moucha Island to be used for commercial farming, particularly using its native brown seaweeds for the industrial production of phycocolloids. Mshigeni (2012-unpubl.) also suggested that these seaweeds should be assessed for their biochemical profiles and economic viability, and that a processing plant could be established to manufacture products for agriculture, livestock and human nutritional and pharmaceutical consumption.

In 2014, the International Fund for Agricultural Development (IFAD), under its project to support coastal fishing areas (PRAREV-PECHE) funded by IFAD and ASAP (Adaption for Smallholder Agriculture Programme), was working on harvesting red and brown seaweeds (species not given) for utilisation in animal feed and to supply the cosmetic market (IFAD-Social reporting Blog). Covering the period 2014-2021, the project addressed the ability of coastal fishers, especially women, to reduce vulnerability and, thus, better adapt to the impact of climate change.

\section{Mauritius and Rodrigues}

Species richness and diversity of seaweeds Mauritius and Rodrigues are Small Island Developing States with limited land resources, but with an extensive Exclusive Economic Zone (EEZ) of about 2.3 million $\mathrm{km}^{2}$ (Narrain et al. 2015a-unpubl.). Despite the reported presence of 435 species of seaweeds in Mauritius and Rodrigues (Bolton et al. 2012; CEVA 2011-unpubl.) and the potential markets for seaweed-derived products, the commercial potential of these resources has received little attention. The Mauritius Research and Innovation Council (MRIC), however, established a research programme in 2008 to investigate the potential for developing an economically, technically and environmentally viable seaweed industry in Mauritius and Rodrigues. The MRIC, working in collaboration with a multidisciplinary team consisting of a number of Ministries and organisations, evaluated the potential commercial utilisation of six native seaweeds including Ulva kylinii, U. lactuca, U. reticulata, Sargassum aquifolium, Gracilaria salicornia and Padina gymnospora. The study found that all six species had the potential for the development of seaweed-based food items, livestock feed supplements, cosmetics and biofertilisers (MRC 2008-unpubl.).

Production volumes, prices and production methods The research programme by MRIC developed local seaweed cultivation techniques and the technology for the processing of commercial products. As a follow-up to this, MRIC sent researchers to Zanzibar for tuition in seaweed farming (Msuya 2011c-unpubl.), followed by hands-on training in Mauritius and Rodrigues, where the first experimental farms were established using native Gracilaria salicornia (Msuya 2011d-unpubl.). Subsequent experimental farms of G. salicornia were established in 2013 in five sites: Albion and Vieux Grand Port in Mauritius and Petite Butte, Jean Tac and Baie du Nord in Rodrigues. Two seaweed farming techniques were evaluated, the raft method in Mauritius and the off-bottom method in Rodrigues. Seaweed growth rates per day obtained were comparable with other Gracilaria species grown in other countries, ranging from 0.66 to $4.96 \%$ (MRC 2013-unpubl.). Yields ranged from 132 to $151 \mathrm{~kg}$ per $100 \mathrm{~m}^{2}$ over four months. Preliminary experimental data indicated that the optimal growth season in Mauritius ranged from April to September, whilst in Rodrigues seaweed could be cultured all year round (Ravina et al. 2015-unpubl.).

The Seaweed Team at MRIC also held several training sessions on seaweed farming and basic seaweed identification with members of the coastal communities, mostly fisherfolks in Rodrigues and the southeast region of Mauritius. At present, community-based seaweed farming is ongoing in Grand Sable (Mauritius) and Baie Du Nord (Rodrigues), and in the former, the Grand Sable Women Planters Farmers Entrepreneurs Association (GSWPFEA), contacted the MRIC in 2013 for technical assistance in setting up a community-based seaweed farm. The GSWPFEA was also successful in gaining funding from the Australian Government. The funding also enabled a mapping exercise to establish the most suitable sites for seaweed cultivation in Grand Sable. A G. salicornia farm was deployed in 2014, using the raft technique over an area of $144 \mathrm{~m}^{2}$. Four PVC rafts of $36 \mathrm{~m}^{2}$, each containing 100 net bags, were established at Grand Sable. The seeding rate was $0.278 \mathrm{~kg}(\mathrm{FW}) \mathrm{m}^{-2}$. A total harvest of $145.2 \mathrm{~kg}(\mathrm{FW})$ was obtained after 19 weeks representing a 3.63 -fold increase. An average harvest of $36.3 \pm 3.06 \mathrm{~kg}$ (FW) $\mathrm{raft}^{-1}$ was recorded with a yield rate of $1.008 \mathrm{~kg}(\mathrm{FW})$ $\mathrm{m}^{-2}$ and a net yield rate of $0.730 \mathrm{~kg}(\mathrm{FW}) \mathrm{m}^{-2}$.

\section{Challenges to sustainable seaweed production in Mauritius and} Rodrigues Mauritius and Rodrigues face frequent typhoons, which makes it difficult to have a year-round sustainable industry. Several attempts to farm seaweeds were affected by typhoons that destroyed the farming devices, such as rafts leading to the loss of the crop (K. Narrain, Pers. Obs.). Equally, the intertidal areas can have high turbidity (Msuya 
2011a), making it difficult for the smallholder farmers to grow seaweeds in these areas, as efficiently as in other African countries. The lack of wild eucheumatoid seaweeds and the ban on importing seaweeds from other countries (CEVA 2011-unpubl., Msuya 2011d-unpubl.) have also led to limited opportunities for producing the red seaweeds, which are commonly farmed in other countries, such as Tanzania, Kenya, Madagascar and Mozambique.

Opportunities for the seaweed industry in Mauritius The Food and Agricultural Research and Extension Institute in Mauritius and Rodrigues, in collaboration with the seaweed farmers, is also actively developing new seaweed-based food products with high commercial potential from G. salicornia. It is also conducting consumer acceptability and shelf-life trials, together with providing training workshops in food processing that can be extended to other products, and the nutritional value of seaweeds. In addition, the University of Mauritius has provided training to members of the GSWPFEA on the construction of solar dryers, to enable the drying of the seaweed, the basics of dehydration and the importance of pre-treatment before drying (MRIC 2014-unpubl.).

In 2015, a study to assess the nutritional profiling of $G$. salicornia harvested from the experimental farms (Narrain et al. 2015b-unpubl.) found that this seaweed had a protein content of $0.74 \pm 0.9 \mathrm{~g}(100 \mathrm{~g})^{-1}(\mathrm{FW})$ and a calcium content of $51 \pm 19 \mathrm{mg}(100 \mathrm{~g})^{-1}(\mathrm{FW})$. These results indicated that this species had a good potential for value addition activities, such as food products and cosmetics.

\section{Southern Africa}

\section{South Africa and Namibia}

Species richness and diversity of seaweeds The marine climate of the west coast of Southern Africa, comprising the Namibian coast and the west coast of South Africa, is influenced by the Benguela Large Marine Ecosystem, one of the world's major upwelling systems. The cool temperate rocky shore communities are dominated by kelp forests, mainly Ecklonia maxima and Laminaria pallida (Bolton and Anderson 1997). The coastline is very straight and mostly exposed to ocean swells (Rothman et al. 2017), with only two large sheltered bays, Lüderitz Bay in southern Namibia and the Saldanha Bay/Langebaan lagoon system in South Africa. The southern coast of South Africa is known as the Agulhas Marine Province, with a different warm temperate biota with high seaweed endemism (Anderson et al. 2009). Further east, this warm temperate biota overlaps with the tropical marine flora of the Southwestern Indian Ocean, and in the extreme east of South Africa, most species are of tropical affinity (Bolton et al. 2004). Namibia has around 200 recorded species of seaweeds (Rull Lluch 2002), whereas, to a large extent because of the three different biotas, South Africa overall has $>850$ species (Bolton and Andersonunpubl.), although the west coast has around 400 species (Stegenga et al. 1997).

South Africa has a long history of seaweed utilisation from natural stocks, with the most important current uses being harvesting of fresh kelp (mostly Ecklonia maxima with some Laminaria pallida) for feed in the abalone aquaculture industry and for the production of growth stimulants in agriculture. There is a dwindling collection of kelp beach cast for alginate, as well as a small, sustainable harvest of the intertidal red seaweed Gelidium pristoides for agar (Anderson et al. 2003, 2010; Rothman et al. 2020). In the past, both countries had large collections of beach cast of Gracilaria, which were dried and shipped overseas for agar production. The latter occurred in both Saldanha Bay (South Africa) and Lüderitz Bay (Namibia), but the large natural stocks have dropped to low levels due to various human activities (Rothman et al. 2009). All material for hydrocolloid production in the region was dried and shipped overseas apart from small operations extracting coarse agar, which were operated for a few years in both South Africa and Namibia (Critchley et al. 1998; Molloy 1998; Anderson et al. 2010).

The current use of natural stocks of seaweeds in Namibia is confined to ca. $150 \mathrm{t}(\mathrm{FW})$ year $^{-1}$ of kelp beach cast (Laminaria pallida), used as feed in a single abalone farm in Lüderitz. In the mid-1980s, the seaweed industry in Lüderitz, based on natural beach cast, employed 250 people (Rotmann 1987). In South Africa, a maximum of ca. $2000 \mathrm{t}$ (FW) of Gracilaria gracilis (Iyer et al. 2005) was collected in 196, and a maximum of $>1500 \mathrm{t}(\mathrm{FW})$ was collected in Namibia in 1988 (Molloy and Bolton 1995; Molloy 1998). There is currently no commercial Gracilaria spp. collection in temperate Southern Africa (Rothman et al. 2020).

Production volumes and prices The current success story of seaweed aquaculture in the region is the production of the green seaweed Ulva spp. on land-based abalone farms, growing Haliotis midae. The most recent official figure was $1644 \mathrm{t}$ (FW) per annum in 2014 (DAFF, 2016-unpubl.), and current production has been estimated at around 2000 $\mathrm{t}$ per annum (Rothman et al. 2020). Official figures are not obtained from farms by the government, as for other aquaculture products, as the seaweed material is not sold, but almost all used as fresh feed. The abalone is fed with formulated feed, usually with the addition of either freshly harvested kelp and/or cultivated Ulva spp. (Bolton et al. 2016; Rothman et al. 2020). Various species names have been used for this Ulva spp. in the literature, but a recent molecular study suggests that the same species is grown in all farms. It was formerly known as Ulva armoricana (Cyrus et al. 
2015), currently considered synonymous with Ulva rigida (Guiry and Guiry, 2021). This material has remained vegetative for many years in the aquaculture systems and does not produce spores/gametes (Bolton et al. 2016). Five farms produce significant amounts of Ulva spp. in ca. $30 \mathrm{~m}$ long, round-ended paddle raceway ponds (Bolton et al. 2009). Each paddle raceway produces ca. 1000-2500 kg Ulva spp. per month, with more in the summer (Bolton et al. 2009). Most of the farms grow the Ulva spp. in abalone effluent, thus practising fully commercially integrated, multi-trophic aquaculture (IMTA). Two of the farms use the Ulva spp. also to remove ammonium from the effluent water (Neveux et al. 2018), saving pumping costs by partial recirculation of ca. $50 \%$ of the water back to the abalone. This can save up to $40 \%$ of farm pumping costs (Nick Loubser, Viking Aquaculture, Pers. Comm.). Other benefits of this partial water recirculation include warming the water, which increases abalone growth rates on the west coast, which can have significant economic benefits (Bolton et al. 2009; Nobre et al. 2010). The integrated aquaculture of Ulva spp. with the South African abalone has been carried out commercially since 2002 and has been used to enable partial water recirculation since 2006 (Rothman et al. 2020). The main threats to this production have been economic (i.e. the value of the coastal land for seaweed rather than abalone production) and biosecurity concerns, with the recirculation of seaweed and water within the farms (Bolton et al. 2009; Rothman et al. 2020). A crustose brown alga, Myrionema strangulans, growing on the Ulva spp. has proved problematic in the past, but was shown to be linked to nutrient depletion and remedied by occasional fertilisation (Robertson-Andersson et al. 2008; Shuuluka 2011). Bioremediation through the Ulva spp. raceways has been shown to reduce levels of both total and harmful bacteria in the recirculated effluent (Jager 2019). Several farms are currently increasing their Ulva spp. production systems considerably, and at least one local company is now including cultured Ulva spp. in its formulated abalone feed (JJ Bolton, Pers. Obs.).

Production methods Following the replacement of Gracilaria spp. beach cast collection with raft cultivation in other countries, especially Chile (Alveal et al. 1997), in situ growth experiments began in 1991 in both Namibia (Molloy and Bolton 1995) and South Africa (Anderson et al. 1996). Initially, pond cultivation was attempted, prompted by a drop in beach cast (Rotmann 1987), which was not continued, but cultivation trials on ropes in Lüderitz Bay led to commercial pilot-scale production (Dawes 1995) and eventually to commercial production (Molloy 1998). A rope-raft system, anchored with ropes using empty soda bottles as floats, was used, which could be extended into 1 and 2 ha units (Dawes 1995). The seaweed was attached using a novel 'hook' method, whereby lengths of 'onion-bag type netting' known as netlon Superope ${ }^{\circledR}$ were laid along a series of coat hooks attached to a board. The Gracilaria spp. was then placed over each hook, and the netlon pulled over the seaweed. As the netlon was pulled taut, the seaweed thalli would become trapped in the meshes: $5 \mathrm{~m}$ lengths of netlon were seeded at $0.4 \mathrm{~kg}$ of seaweed $\mathrm{m}^{-1}$ (Molloy 1998). The strings of netlon containing the seaweed were then ferried by boat to the floating rafts and tied to ropes, where they rested just below the surface. This method is described in detail by Dawes (1995). Relative growth rates in winter of ca. $5-11 \%$ per day were reported. A maximum of 10 ha under cultivation was achieved in 1994, but despite holding the rafts in place with 5t concrete blocks and pipe anchors, a major problem was specific conditions of currents in the bay, which resulted in the aquaculture systems becoming tangled and washed ashore. Pulfrich (2010-unpubl.) reported a production figure of 280-360 t (FW) per annum in Lüderitz Lagoon, but this was discontinued due to financial constraints following further damage due to sea current conditions in the bay.

Currently, there is no seaweed aquaculture in Namibia. In South Africa, Gracilaria spp. rope-raft culture has never been practised commercially, despite successful experimental studies. These trials in Saldanha Bay used the same roperaft methods as Dawes (1995), and commercial-style lines of plastic netting (netlon) stocked at $400 \mathrm{~g} \mathrm{~m}^{-1}$ and placed $0.75 \mathrm{~m}$ apart, which yielded a mean of about $2 \mathrm{~kg} \mathrm{~m}^{-2}$ 30 day $^{-1}$, with a mean RGR of about $5 \%$ day $^{-1}$ over a 2 -year period, with higher growth rates in summer than winter (Anderson et al. 1996). A potential problem in Saldanha Bay involved stratification in late summer, where growth was low in the upper, nutrient-poor layer (Anderson et al. 2010). This was mitigated in some areas by nutrients derived as waste from a fish plant, although this fish factory is no longer in operation. Similar studies were carried out in a relatively sheltered section of the nearby open coast in St. Helena Bay (Wakibia et al. 2001; Anderson et al. 2003). Two different species were tested, Gracilariopsis sp. (Gracilariopsis longissima) (Iyer et al. 2005) and Gracilaria gracilis, with seasonal growth rates ranging from $4.0-11.0$ to $5.0-7.0 \%$ day $^{-1}$, respectively. There were no seasonal nutrient deficiencies, although periodic low-oxygen hydrogen sulphide events (known as black tides) killed all inshore marine life, including the cultivated seaweeds in 1994 and 1998. Following these studies, a number of companies expressed interest in seaweed aquaculture at both sites, and at least one carried out commercial trials in Saldanha Bay, but none of these were successful. The lack of policy and legislation was a major drawback in gaining permission for seaweed aquaculture in St Helena Bay.

Several land-based abalone farms in South Africa grow small amounts of G. gracilis, which farmers consider to be useful as feed, particularly for juvenile abalone. Only one farm grows significant amounts, which total ca. $570 \mathrm{t}$ per 
annum, in 260 round, aerated tanks (Wild Coast Abalone, Pers. Comm.). Problems with epiphytes growing on the Gracilaria (ectocarpoids and diatoms) are solved by their manual removal from the seedling stock.

In addition, there have been experimental attempts to grow Gelidium pristoides on the south coast of South Africa (Aken et al. 1993; Steyn 2009) and G. vittatum (as Suhria vittata) on the west coast (Anderson and Bolton 1985), which were unsuccessful, as has been the case worldwide with Gelidium species, leading to a global shortage of Gelidium agar (Santos and Melo 2018).

Challenges and opportunities to sustainable seaweed production in South Africa Despite the globally significant kelp forests on the west coast of Southern Africa, there has been no commercial aquaculture of kelps (Laminariales) in the region thus far. Some studies on the growth of the microscopic stages have been completed in the laboratory (Bolton and Levitt 1985; Bolton and Anderson 1987; Rothman 2015), and both the major kelp species (Ecklonia maxima and Laminaria pallida) have been grown from spores to large kelp sporophytes in the sea (Rothman 2015). Ecklonia maxima plants can be very large, as long as $17 \mathrm{~m}$, although most of the length and half of the biomass is stipe. Macrocystis pyrifera (known as 'giant kelp' in other world region) also occurs naturally in South Africa, but only in a few small beds in the southwest, and does not grow naturally in Namibia (Fleischman et al. 2020). A small experimental study grew this species successfully from regenerating holdfasts on rope rafts in Saldanha Bay (Fleischman et al. 2021). There is increasing commercial interest in pursuing kelp aquaculture in the region and a company (Kelp Blue) has recently been set up in Namibia and has currently received approval of Environmental Impact Assessment for a pilot aquafarm, intending to produce large amounts of kelp offshore: http://kelp.blue/namibia/.

\section{West Africa}

\section{Ghana}

Species richness and diversity of seaweeds About 200 species have been reported in Ghana (Bolton et al. 2003). Ghana, however, faces the problem of volumes of floating seaweeds that are cast on its beaches. These floating seaweed (Sargassum spp.) masses are a recent major global phenomenon, stretching across the central Atlantic Ocean and causing problems with large beach casts from Mexico to Ghana (Smetacek and Zingone 2013); (Ackah-Baidoo 2013). A study of Ghanian seaweeds assessed the potential of six red seaweed species in fighting pollution by acting as biological indicators for heavy metals Serfor-Armah et al.
(2001). Serfor-Armah et al. (2006) studied 23 heavy metals in seven species of Rhodophyta, five species of Chlorophyta and three species of Phaeophyceae as potential candidates for monitoring pollution.

Seaweed utilisation Until 2017, the Ghanian seaweed industry was primarily based on the harvesting of wild seaweeds from the significant beach cast, primarily Sargassum spp., which was used to generate income for the communities (Jensen 2015-unpubl.). A collaborative programme between the Technical University of Denmark (DTU), the Council for Scientific and Industrial Research (CSIR) and Kwame Nkrumah University of Science and Technology (KNUST) in Ghana assessed the potential of using the cast seaweed to generating economic growth, with the aim of establishing a seaweed processing industry and eventually developing a cultivation industry, when appropriate technologies were found (Jensen 2015-unpubl.). A biorefinery project (Seaweed Bio-refinery Project of Ghana (SeaBioGha) has also been implemented by DTU, KNUST, CSIR and the Water Research Institute of Ghana (WRIG), to "manage the seaweed menace along the coast" and to establish a "massive" seaweed cultivation initiative along the $540 \mathrm{~km}$ stretch of coastline in Ghana. The plan being that the cultivated seaweed would predominantly be used to produce value-added products and the by-product would be used in the biorefinery (Segbefia et al. 2018).

Opportunities for the seaweed industry in Ghana Since 2017, the cultivation of Kappaphycus spp. and Eucheuma spp. in Ghana (using imported seaweed) has been practised by farmers in two villages-Half Asini (Southwest Ghana) and New Takoradi (Southern Ghana) (Agyarko 2017). Studies have also assessed the socio-economic significance of seaweed farming in Ghana (Agyarko 2017), as a new and opportunistic industry, and highlighted 12 potential areas suitable for farming (Segbefia et al. 2018). Gbedemah (2014) also highlighted additional potentially suitable species for cultivation and wild collection in Ghana including: Sargassum vulgare, Hypnea musciformis and Ulva fasciata.

\section{Nigeria}

Species richness and diversity of seaweeds Nigeria has approximately 79 species of seaweed that have been identified, with the majority composed of red algae ( 38 species) (Fakoya et al 2011; Solarin et al. 2014). Sargassum spp. form seasonal blooms, which when cast upon the beaches places a high financial cost on the country for clearance (Solarin et al. 2014). This alga can also interfere with navigation activities and can clog fishing nets causing extra work for the fishermen (Solarin et al. 2014). The significant blooms in Nigeria have been linked to the increased nutrients transported by 
the Guinea Current, which originates from the North Equatorial Counter Current (NECC) and flows eastward along the western coast of Africa (Hénin and Hisard 1987; Hormann et al. 2012; Pelegrin and Pena-Izquierdo, 2015).

Seaweed utilisation Efforts have been made to convert Sargassum spp. into economically beneficial products, such as alginates, as well as cultivating other algae such as Ulva spp. (Ibraheem et al. 2017). Solarin et al. (2014) also studied Sargassum fluitans (as S. hystrix var. fluitans) for its proximate composition, mineral content and potential application in agriculture. In addition, Abowei and Tawari (2011) and Fakoya et al. (2011) recommended several species of seaweeds in the genera Sargassum, Ulva, Gracilaria and Chaetomorpha for human, medical, industrial, agricultural and environmental related uses.

Opportunities for the seaweed industry in Nigeria With a coastline of $860 \mathrm{~km}$ extending from the border with Benin in the West to Cameroon in the East, Nigeria has potential for seaweed farming. Several authors have recommended the initiation of seaweed farming in Nigeria, using mainly native species, but also imported species where necessary with appropriate farming technologies. Abowei and Tawari (2011) argued that with the well-known uses and benefits of the brown seaweeds, it may be useful to import and cultivate the appropriate Phaeophyceae species from other west African countries, such as Ghana, Togo and Cameroon, countries whose ecology is similar to Nigeria, as well as the red seaweed Eucheuma spp. from where it is currently cultivated. These authors, as well as Fakoya et al (2011), also recommended the use of farming methods, such as rafts. Ibraheem et al. (2017) pointed out that Nigeria should consider farming seaweed for biomass production, as is done in other countries.

\section{Senegal}

Species richness and diversity of seaweeds In Senegal, there are over 400 seaweed species reported on its coastal area (Ndiaye et al. 2021-unpubl.). Efforts to study seaweed resources of Senegal include a study by Ndiaye et al. (2021-unpubl.), who pointed out that CLIMALG-SN was compiling a list of seaweed species found in Senegal aiming at both harvesting from the wild and cultivation.

Seaweed utilisation and opportunities for the seaweed industry in Senegal Efforts to start a seaweed industry based on both wild collection and farming were reported by JICA (JICA-undated), in collaboration with the University of Cheikh Anta Diop in Dakar based on Hypnea musciformis and Meristotheca senegalensis. These efforts were mentioned by McHugh (2002), who stated that there had been interest in harvesting the naturally growing $\mathrm{H}$. musciformis for economic uses. According to the author, there was a company that had shown interest in harvesting and processing the H. musciformis around 2001-2002. Seaweed production in Senegal was reported recently (Gueye et al. 2020), with an estimated $80-100 \mathrm{t}$ (FW) being exported to Japan.

\section{Northern Africa}

\section{Morocco}

Species richness and diversity of seaweeds A total of 394 seaweed species were reported in Morocco by 2003, including 102 species of Chlorophyceae (Benhissoune et al. 2001), 131 species of Phaeophyceae (Benhissoune et al. 2002) and 161 species of Rhodophyceae (Benhissoune et al. 2003). Equally, Moussa et al. (2018), working in the Al-Hoceima National Park, reported 306 algal taxa including 207 red, 51 brown and 48 green seaweed and stated that amongst these were records of 10 new species. In a more recent study, Bahammou et al. (2021) reported 156 species from 35 families of Rhodophyta. The authors reported two species that were recorded for the first time in Morocco-Gaillona gallica and Aglaothamnion tripinnatum Of all these species, however, only a few have been exploited for commercial and community economic development. Rhimou et al. (2010) pointed out that the coast of Morocco is rich in seaweed biodiversity, which could be exploited for economic, social and ecological potentials, but only Gelidium corneum (as Gelidium sesquipedale) had been exploited by 2010. Gracilaria multipartita, however, has also been recommended as a good source of agar (Noura et al. 2014).

Seaweed utilisation The seaweed industry in Morocco, located in the northwest, is based predominantly on the extraction of agar from wild populations of Gelidium spp. (Kassila et al. 2019). It has been reported, however, that wild populations of the seaweed, commonly called "red gold", are decreasing because of overharvesting for agaragar production (Makhfi (2015-unpublished). The information from this link adds that, indeed, the supply to the red gold processing industry situated in Kenitra, Rabat, which uses $80 \%$ of the harvested seaweed is decreasing. Two companies, however, 'The Seaweed Company' and 'Morocco Seaweed' are still involved in the seaweed industry. The former is reportedly cultivating, harvesting and processing seaweed at a commercial scale at its processing plants situated in Morocco, as well as Ireland and India (The Seaweed Company-unpublished online information), whereas the latter states that it supplies and exports red seaweeds 
Gracilaria spp., Gigartina spp. and Gelidium spp., as well as the brown seaweed Laminaria from Morocco (Morocco Seaweed Supplier-unpublished online information). The invasive seaweed Sargassum muticum is also harvested and converted to alginate and defined as a potential commercial commodity and source of livelihood in Morocco (El Atouani et al. 2016). The potential of Moroccan seaweeds for pharmaceutical applications has also been studied by Rhimou et al. (2010), who investigated 55 aqueous extracts from 16 species of red seaweeds as sources of anti-viral compounds. Out of these, 10 species including Asparagopsis armata, Ceramium rubrum, Gelidium pulchellum, Gelidium spinulosum, Halopitys incurvus, Hypnea musciformis, Plocamium cartilagineum, Vertebrata thuyoides, Pterosiphonia complanata and Sphaerococcus coronopifolius were identified as potential sources. Equally, Rhimou et al. (2010) studied extracts from 26 red seaweeds including Hypnea, Halopithys and Gelidium for their potential antibacterial activities. Potential of polysaccharide-enriched extracts (PEEs) from 17 seaweeds in Morocco as plant growth stimulators was also reported by Mzibra et al. (2018), who showed that six out of the 17 species including Ulva rigida, Gigartina sp. and Fucus spiralis had high potential.

Opportunities for the seaweed industry in Morocco Owing to the rising demand for agar production, Gracilaria has also been identified for potential cultivation. The National Agency for Aquaculture Development (ANDA) has identified sites that are suitable for the cultivation of the agarproducing red seaweed Gracilaria. These sites include Sidi Rahal, Nador Lagoon and Dhakhla Bay, located in Northwest Atlantic Ocean, Northeast Mediterranean Sea and the Southwest Atlantic Ocean coast, respectively (Kassila et al. 2019). Plans to develop seaweed cultivation in the country began in 2000, when coastal spatial planning for marine aquaculture site selection was initiated (Sanchez-Jerez et al. 2016). Subsequently, fishermen in Nador Lagoon, working with ANDA and the National Institute of Fisheries Research (INRH), formed a cooperative in 2013 and secured funding from the Global Environment Fund and the World Bank to produce 13,000 t (FW) of Gracilaria gracilis (Kassila et al. 2019). Initial trials conducted by Kassila et al. (2019) to cultivate G. gracilis in Nador Lagoon used the traditional off-bottom and floating lines methods. Daily growth rates of 1.9-2.8 day ${ }^{-1}$ were recorded, the higher growth rates typically observed in the floating lines compared with the off-bottom method. The authors demonstrated that seaweed farming was possible in Morocco and that it was suitable for small-scale fishermen, who were able and willing to switch from an exclusive dependence on capture fisheries to an intensive involvement in seaweed farming. By 2019, however, there was only one seaweed export company,
SETEXAM, which set the seaweed price at US\$ $0.52 \mathrm{~kg}^{-1}$ of dry seaweed paid to farmers (Kassila et al. 2019).

Plans to launch a further 24 shellfish and seaweed projects in Souss Massa (southern Morocco) by the National Agency for Development of Aquaculture were also announced in 2020 (https://www.undercurrentnews.com/2020/11/09/ morocco-launches-24-new-shellfish-seaweed-farms-in-latest-development-project/).

\section{Tunisia}

Species richness and diversity of seaweeds Benhissoune et al. (2001) reported that Tunisia had 64 taxa (species and sub-species) and Benhissoune et al. (2002) reported 87 taxa. There have been very few studies, however, to assess their economic potential (Yaich et al. 2011). Ulva lactuca, collected between Taboulba and Sayada, was identified though as a potential source of dietary fibre, essential amino acids and fatty acids (Yaich et al. 2011).

Production methods A mixture of production methods is used in Tunisia. SELT MARINE GROUP (2021)reports cultivation methods in Tunisia to have included off-bottom method (for Kappaphycus spp. and Eucheuma spp.), long lines (for Gracilaria spp.) and recently tubular nets (for the cultivation of Gracilaria spp.). Bamboo rafts have also been mentioned by SELT MARINE (2021).

Opportunities for the seaweed industry in Tunisia The presence of a seaweed processing plant and plans of expanding seaweed cultivation in Tunisia offer opportunities for the expansion of seaweed production and valorisation in the country. Gracilaria spp. is cultivated and processed in Tunisia by SELT MARINE GROUP. The company produces and markets agar and carrageenan from Gracilaria spp., together with $K$. alvarezii and $E$. denticulatum grown in Tanzania and Mozambique (see previous sections) as well as in Asia. SELT MARINE currently has an 80-hectare site in Tunisia growing Gracilaria spp., located in the salt-water Bizerte Lake, near Jadara.

\section{African seaweed industry}

As is the case with all continents, with the exception of Asia, there is only limited cultivation of seaweeds in Africa, to date. The continent does, however, have one major cultivated seaweed-producing country (i.e. Tanzania), and a number of other countries are cultivating a range of seaweeds at a commercial scale. This makes Africa, as a whole, the second-highest continent, after Asia, for global seaweed aquaculture production (FAO 2020). The continent also has over 
30 years' experience in cultivating seaweeds. Tanzania and Madagascar are amongst the major producers of eucheumatoids in the world. Many of the emerging countries in seaweed production (i.e. Kenya, Mozambique and Namibia) have the potential to significantly expand their operations. Others, such as Somalia, recognise the potential of seaweed farming as a community development initiative and are planning a new industry in Puntland State through its NGO Somali Women Action (F. Msuya, Pers. Comm. with the NGO). A number of other countries have at least experimented in the cultivation of seaweeds or are farming in small quantities. For example, eucheumatoids in Djibouti and Ghana; Gracilariales in South Africa, Namibia, Morocco, and Tunisia; and Ulva spp. in South Africa. There are also countries in Africa that farm seaweed purely for domestic utilisation, such as Gracilaria spp. for making products in Mauritius and Rodrigues and Ulva spp. and Gracilaria spp. for feeding abalone in South Africa and Namibia. In Africa, many countries also have experience in processing seaweed based on harvesting from the wild (Tunisia, Senegal and Morocco) and selling it commercially (Sargassum spp. in Ghana, Nigeria), for inclusion in animal feed (South Africa, Namibia), plant biostimulants (South Africa) or as sources of marine products in biotechnology (Ghana, Morocco). The effort in Namibia by the company Kelp Blue also aims to use a biorefinery process, to produce a number of products from large amounts of kelp biomass grown offshore for the first time in Africa.

In Africa, almost all the major groups of economic seaweeds are cultivated: tropical Eucheuma spp./Kappaphycus spp., kelp in temperate Southern Africa and both temperate and tropical Gracilariales. There is also potential for use of Sargassum in many warmer regions, and species of Porphyra spp. and its relatives grow naturally in southern Africa, which could be cultivated for nori. In addition, all coastal countries in Africa have species of seaweed growing naturally, which could be marketed as food/feed products to aid in various aspects of human and livestock nutrition. A number of other naturally growing seaweeds have been recommended for commercial exploitation as food or source of income. The tropical species Asparagopsis taxiformis, for example grows on both east and west coasts, and the more temperate species A. armata grows in both South Africa and the North African Atlantic/Mediterranean (Bolton et al. 2011; Guiry and Guiry 2021). This genus has received increasing attention recently, as it can significantly reduce methane emission when fed to ruminant livestock (Kinley et al. 2016; Roque et al. 2021). The availability of a large range of marine environments and habitats (two climates tropical and temperate), an extensive coastline and sea area, encompassing the Atlantic and Indian Oceans, plus the Mediterranean Sea, provides the opportunity for the continent of Africa to respond to all aspects of the recently discussed
'Seaweed Revolution'. The United Nations Global Compact Dialogue on 'Powering the seaweed revolution as a gamechanger for our food system' was held in April 2021 and had a significant focus on Africa. With this scenario in Africa, there is a high potential to expand the seaweed industry and to make this continent one of the main centres for seaweed cultivation and utilisation worldwide. There is a need for unified efforts (e.g. by engaging with the newly formulated Safe Seaweed Coalition, which aims at Revolutionising Seaweed in Africa) to advance the seaweed industry in Africa (see the website information at https://www.safeseaweedcoal ition.org).

\section{Conclusion}

Coastal African countries are rich in seaweed species and many have suitable areas that can be used for cultivating and processing many types of seaweeds. These countries have the potential to use its rich, natural seaweed biodiversity for economic benefits of their people (by harvesting responsibly and sustainably) and cultivating native seaweeds, or imported species when necessary, depending on the country and species required, for both food and income generation. Importantly, with evidence-based research to study the wider benefits of seaweeds in African waters, such as the potential for ecosystem restoration, services and carbon capture, seaweeds can be an important new crop for many countries. A number of coastal African countries have recognised the benefits of seaweeds and are putting efforts into responsibly developing their resources, whether it is through wild harvest or cultivation and valorisation. With such rich resources, the efforts done so far to cultivate and process seaweed, Africa could be one of the continents that produces and processes seaweeds in large quantities, on a scale similar to Asia. With careful management and utilisation of its resources including biosecurity efforts to reduce the introduction and spread of pests and diseases (e.g. restricted importation, observing quarantine protocols for movement of seed, regular monitoring) and protecting its natural seaweed beds (Cottier-Cook et al. 2021), Africa has the ability to establish a significant seaweed industry. These aspects call for linkages and collaboration between and amongst countries to look at possibilities of making the farming of seaweeds in Africa a one-continent industry, which benefits all stakeholders.

Acknowledgements FEM and EJC are researchers under the "GlobalSeaweedSTAR" Programme (Grant No. BB/P027806/1) supported by the United Kingdom Research and Innovation-Global Challenges Research Fund (UKRI-GCRF). 
Data availability All the data in this manuscript were produced through the authors' research work. Data is openly available and can be obtained by asking the authors.

Open Access This article is licensed under a Creative Commons Attribution 4.0 International License, which permits use, sharing, adaptation, distribution and reproduction in any medium or format, as long as you give appropriate credit to the original author(s) and the source, provide a link to the Creative Commons licence, and indicate if changes were made. The images or other third party material in this article are included in the article's Creative Commons licence, unless indicated otherwise in a credit line to the material. If material is not included in the article's Creative Commons licence and your intended use is not permitted by statutory regulation or exceeds the permitted use, you will need to obtain permission directly from the copyright holder. To view a copy of this licence, visit http://creativecommons.org/licenses/by/4.0/.

\section{References}

Abowei JFN, Tawari CC (2011) A review of the biology, culture, exploitation and utilization potentials seaweed resources: case study in Nigeria. Res J Appl Sci Eng Technol 3:290-303

Ackah-Baidoo A (2013) Fishing in troubled waters: oil production, seaweed and community-level grievances in the Western Region of Ghana. Community Dev J 48:406-420

Agyarko KA (2017) Assessing the socio-economic benefits of seaweed production to the rural coastal areas in Ghana. Int J Adv Sci Eng Technol 3:32-39

Aken ME, Griffin NJ, Robertson BL (1993) Cultivation of the agarophyte Gelidium pristoides in Algoa Bay, South Africa. Hydrobiologia 268:169-184

Alveal K, Romo H, Werlinger C, Oliveira EC (1997) Mass cultivation of the agar-producing alga Gracilaria chilensis (Rhodophyta) from spores. Aquaculture 148:77-83

Amosu AO, Robertson-Andersson DV, Kean E, Maneveldt GW, Cyster L (2016) Biofiltering and uptake of dissolved nutrients by Ulva armoricana (Chlorophyta) in a land-based aquaculture system. Int J Agric Biol 18:298-304

Anderson RJ, Bolton JJ (1985) Suitability of the agarophyte Suhria vittata (L.) J. Ag. (Rhodophyta: Gelidiaceae) for mariculture: geographical distribution, reproductive phenology and growth of sporelings in culture in relation to light and temperature. S Afr J Mar Sci 3:169-178

Anderson RJ, Levitt GJ, Share A (1996) Experimental investigations for the mariculture of Gracilaria in Saldanha Bay, South Africa. J Appl Phycol 8:421-430

Anderson, RJ, Boothroyd, CJT, Kemp, FA, Rothman, M (2001) Openwater cultivation of Gracilaria in South Africa: Saldanha Bay or St Helena Bay? In: Chapman, ARO, Anderson, RJ, Vreeland, VJ, Davison, IR (eds) Proceedings of the 17th International Seaweeds Symposium. Oxford University Press, Oxford pp. 35-40

Anderson RJ, Bolton JJ, Molloy FJ, Rotmann KWG (2003) Commercial seaweeds in southern Africa. In: Chapman ARO, Anderson RJ, Vreeland VJ, Davison IR (eds) Seventeenth Proceedings of the $17^{\text {th }}$ International Seaweeds Symposium. Oxford University Press, Oxford pp 1-12

Anderson RJ, Bolton JJ, Stegenga H (2009) Using the biogeographical distribution and diversity of seaweed species to test the efficacy of marine protected areas in the warm-temperate Agulhas Marine Province, South Africa. Divers Distrib 15:1017-1027
Anderson RJ, Simons RH, Jarman NG (2010) Commercial seaweeds in Southern Africa: a review of utilization and research. S Afr J Mar Sci 8:277-299

Arori MK, Muthumbi AWN, Mutia GM, Nyonje B (2019) Potential of seaweeds (Hypnea cornuta and Hypnea musciformis) in Nile tilapia (Oreochromis niloticus) fingerlings diets. Int J Fish Aquat Stud 7:103-107

Bahammou N, Cherifi O, Bouamama H et al (2021) Checklist of Rhodophyceae and the first report of Aglaothamnion tripinnatum and Gaillona gallica in the Moroccan coastline. Egypt J Aquat Res 47:101-107

Benhissoune S, Boudouresque CF, Verlaque M (2001) A checklist of the seaweeds of the Mediterranean and Atlantic coasts of Morocco. I. Chlorophyceae Wille $s$ l. Bot Mar 44:171-182

Benhissoune S, Boudouresque CF, Verlaque M (2002) A checklist of the seaweeds of the Mediterranean and Atlantic coasts of Morocco. II. Phaeophyceae. Bot Mar 45:217-230.

Benhissoune S, Boudouresque CF, Perret-Boudouresque M, Verlaque M (2003) A checklist of the seaweeds of the Mediterranean and Atlantic coasts of Morocco. IV. Rhodophyceae - Ceramiales. Bot Mar 46:55-68.

Bolton JJ, Anderson RJ (1987) Temperature tolerances of two southern African Ecklonia species (Alariaceae: Laminariales) and of hybrids between them. Mar Biol 96:293-297

Bolton JJ, Anderson RJ (1997) Marine vegetation. In: Cowling RM, Richardson DM, Pierce SM (eds) Vegetation of Southern Africa. Cambridge University Press, Cambridge, pp 348-370

Bolton JJ, Levitt GJ (1985) Light and temperature requirements for growth and reproduction in gametophytes of Ecklonia maxima (Alariaceae: Laminariales). Mar Biol 87:131-135

Bolton JJ, Clerck O De, John DM (2003) Seaweed diversity patterns in Sub-Saharan Africa. In: Decker C, Griffith C, et al. (eds) Proceedings of sub-Saharan African marine biodiversity workshop. Cape Town. pp 229-241

Bolton JJ, Leliaert F, De Clerck O, Anderson RJ, Stegenga H, Engledow HE, Coppejahns E (2004) Where is the western limit of the tropical Indian Ocean seaweed flora? An analysis of intertidal seaweed biogeography on the east coast of South Africa. Mar Biol 144:51-59

Bolton JJ, Oyieke HA, Gwada P (2007) The seaweeds of Kenya: checklist, history of seaweed study, coastal environment, and analysis of seaweed diversity and biogeography. S Afr J Bot 73:76-88

Bolton JJ, Robertson-Andersson DV, Shuuluka D, Kandjengo L (2009) Growing Ulva (Chlorophyta) in integrated systems as a commercial crop for abalone feed in South Africa: a SWOT analysis. J Appl Phycol 21:575-583

Bolton JJ, Andreakis N, Anderson RJ (2011) Molecular evidence for three separate cryptic introductions of the red seaweed Asparagopsis (Bonnemaisoniales, Rhodophyta) in South Africa. African J Mar Sci 33:263-271

Bolton JJ, Bhagooli R, Mattio L (2012) The Mauritian Seaweed Flora: Diversity and Potential for Sustainable Utilisation. University of Mauritius Research Journal, Special Issue on Sustainable Marine Environment - Volume 18A University of Mauritius, Réduit, Mauritius

Bolton JJ, Cyrus MD, Brand MJ, Joubert M, Macey BM (2016) Why grow Ulva? Its potential role in the future of aquaculture. Perspect Phycol 3:113-120

Bongani V, Chipo U, Dakarai H (2013) South African seaweed aquaculture: a sustainable development example for other African coastal countries. African J Agric Res 8:5268-5279

Braud J, Perez R (1978) Farming on pilot scale of Eucheuma spinosum (Florideophyceae) in Djibouti waters. In: Jensen A, Stein JR (eds) Proceedings of the ninth International Seaweed Symposium. Science Press, Princeton, pp 533-539 
Brugere C, Msuya FE, Jiddawi N, Nyonje B, Maly R (2020) Can innovation empower? Reflections on introducing tubular nets to women seaweed farmers in Zanzibar. Gend Technol Dev 24:89-109

Bryceson I, Massinga A (2002) Coastal resources and management systems influenced by conflict and migration: Mecúfi, Mozambique. Ambio 31:512-517

Buriyo A, Kivaisi A (2003) Standing Stock, agar yield and properties of Gracilaria salicornia harvested along the Tanzanian coast. Western Indian Ocean J Mar Sci 2:171-178

Campbell I, Kambey CSB, Mateo JP, Rusekwa SB, Hurtado AQ, Msuya FE, Stentiford GD, Cottier-Cook EJ (2020) Biosecurity policy and legislation for the global seaweed aquaculture industry. J Appl Phycol 32:2133-2146

Carvalho, AM, Bandeira, SO (2003) Seaweed flora of Quirimbas Archipelago, northern Mozambique, In: Chapman ARO, Anderson RJ, Vreeland VJ and Davison IR (eds). Proceedings of the XVIIth International Seaweed Symposium, Cape Town, South Africa. Oxford University Press, Oxford pp 319-324

Cottier-Cook EJ, Nagabhatla N, Badis Y, et al (2016) Safeguarding the future of the global seaweed aquaculture industry. United Nations University (INWEH) and Scottish Association for Marine Science Policy Brief. https://inweh.unu.edu/wp-content/uploads/ 2016/09/unu-seaweed-aquaculture-policy.pdf

Cottier-Cook, EJ, Nagabhatla, N, Asri, A, et al (2021) Ensuring the sustainable future of the rapidly expanding global seaweed aquaculture industry - a vision. United Nations University Institute on Comparative Regional Integration Studies and Scottish Association for Marine Science Policy Brief. \#06 2021

Critchley AT, Aken ME, Bandeira S, Kalk M (1997) A revised list of seaweeds from Inhaca Island, Mozambique. S Afr J Bot 63:426-435

Critchley AT, Gillespie RD, Rotmann KWG (1998) The seaweed resources of South Africa. In: Ohno M, Critchley AT (eds) Seaweed resources of the world. Kanagawa International Fisheries Training Center, Japan International Cooperative Agency, Yokosuka pp 413-427

Cyrus MD, Bolton JJ, Macey BM (2015) The role of the green seaweed Ulva as a dietary supplement for full life-cycle grow-out of Tripneustes gratilla. Aquaculture 446:187-197

Dawes CP (1995) Suspended cultivation of Gracilaria in the sea. J Appl Phycol 7:303-313

de Jager K (2019) Microorganisms associated with Ulva grown in abalone effluent water: implications for biosecurity. MSc Thesis, University of Cape Town.

El Atouani S, Bentiss F, Reani A, Zrid R, Belattmania Z, Pereira L, Mortadi A, Cherkaoui O, Sabour B (2016) The invasive brown seaweed Sargassum muticum as new resource for alginate in Morocco: spectroscopic and rheological characterization. Phycol Res 64:185-193

Fakoya KA, Owodeinde FG, Akintola SL, Adewolu MA, Abass MA, Ndimele PEN (2011) An exposition on potential seaweed resources for exploitation, culture and utilization in West Africa: a case study of Nigeria. J Fish Aquat Sci 6:37-47

FAO (undated) National Aquaculture Sector Overview - Mozambique. https://www.fao.org/countrysector/naso_mozambique. Accessed May 2021

FAO (2020) The State of World Fisheries and Aquaculture 2020. Sustainability in action. FAO, Rome

Filbee-Dexter K, Wernberg T (2020) Substantial blue carbon in overlooked Australian kelp forests. Sci Rep 10:12341

Fleischman MJ, Bolton JJ, Rothman MD (2020) Macrocystis (Laminariales, Phaeophyceae) in South Africa: distribution, morphology, and potential susceptibility to warming events. J Appl Phycol 32:2447-2457
Fleischman MJ, Bolton JJ, Rothman MD (2021) Macrocystis (Laminariales, Phaeophyceae) in South Africa: potential for cultivation through holdfast fragmentation and use as feed for the aquacultured abalone, Haliotis midae. J Appl Phycol 33:1731-1740

Fourreh AE, Abdoul-Latif FM, Ibrahim MN, Ali AM (2019) Antioxidant activity and phenolic contents of seven brown seaweed from Djibouti coast. Int J Curr Pharm Res 11:42-44

Gbedemah TS (2014) Intertidal macro-algal diversity and zonation patterns of the eastern and western coasts of Ghana. University of Ghana

Góes HG, Reis RP (2011) An initial comparison of tubular netting versus tie-tie methods of cultivation for Kappaphycus alvarezii (Rhodophyta, Solieriaceae) on the south coast of Rio de Janeiro State, Brazil. J Appl Phycol 23:607-613

Góes HG, Reis RP (2012) Temporal variation of the growth, carrageenan yield and quality of Kappaphycus alvarezii (Rhodophyta, Gigartinales) cultivated at Sepetiba bay, southeastern Brazilian coast. J Appl Phycol 24:173-180

Gueye MF, Mbaye MS, Ka SL, Diouf J, Dieng B, Sidybe M, Noba K (2020) Taxonomy diversity and abundance of seaweeds in the northern Atlantic coast of Senegal (West Africa). Scholars Acad J Biosci 8:360-370

Guiry, M.D. \& Guiry, G.M. 2021. AlgaeBase. World-wide electronic publication, National University of Ireland, Galway. https://www. algaebase.org. Accessed March 2021

Hayashi L, Hurtado AQ, Msuya FE, Bleicher-Lhonneur G, Critchley AT (2010). A review of Kappaphycus farming: Prospects and constraints. In: A. Israel, R. Einav J. Seckbach (eds.). Seaweeds and their Role in Globally Changing Environments, Cellular Origin, Life in Extreme Habitats and Astrobiology. 15:251-283

Hénin C, Hisard P (1987) The North Equatorial Countercurrent observed during the Programme Francais Ocean Climat dans l'Atlantique Equatorial experiment in the Atlantic ocean, July 1982 to August 1984. J Geophys Res Ocean 92:3751-3758

Hormann V, Lumpkin R, Foltz GR (2012) Interannual North Equatorial Countercurrent variability and its relation to tropical Atlantic climate modes. J Geophys Res Ocean 117:1-17

Ibraheem O, Komolafe TO, Bawa E, Oluwole JO (2017) Preliminary evaluation of Nigeria coastal line seaweeds for the alginate content and biochemical constituents. J Environ Biotechnol Res 6:220-227

Iyer R, Tronchin EM, Bolton JJ, Coyne VE (2005) Molecular systematics of the Gracilariaceae (Gracilariales, Rhodophyta) with emphasis on southern Africa. J Phycol 41:672-684

Kambey CSB, Campbell I, Sondak CFA, Nor ARM, Lim PE, CottierCook EJ (2020) An analysis of the current status and future of biosecurity frameworks for the Indonesian seaweed industry. J Appl Phycol 32:2147-2160

Kassila J, Nhhala H, Givernaud T, Monsouri M, Yazami O, Abrehouch A, Mosfioui A, Indahala M (2019) Opportunities for the development of seaweed farming as a supplementary income for small-scale fishermen in Nador lagoon: experimental cultivations of Gracilaria gracilis (Stackhouse). Med Fish Aquacult Stud 2:12-26

Kelp Blue (2020) http://eia.met.gov.na/screening/1409_kelp_blue eiareport_31aug20_final_to_meft_and_mfmr_f.pdf). Accessed May 2021

Kimathi AG, Wakibia JG, Gichua MK (2018) Growth rates of Eucheuma denticulatum and Kappaphycus alvarezii (Rhodophyta; Gigartinales) cultured using modified off-bottom and floating raft techniques on the Kenyan coast. Western Indian Ocean J Mar Sci 17:11

Kinley RD, De Nys R, Vucko MJ, Machado L, Tomkins NW (2016) The red macroalgae Asparagopsis taxiformis is a potent natural antimethanogenic that reduces methane production 
during in vitro fermentation with rumen fluid. Anim Prod Sci 56:282-289

Krause-Jensen D, Lavery P, Serrano O, Manba N, Masque P, Duarte CM (2018) Sequestration of macroalgal carbon: the elephant in the Blue Carbon room. Biol Lett 14:20180236

Largo DB, Msuya FE, Menezes A (2020) Understanding diseases and control in seaweed farming in Zanzibar. FAO Fisheries and Aquaculture Technical Paper No. 662.

Massingue AO, Bandeira SO (2005) Distribution of seagrasses and common seaweeds around Nampula Province (Northern Mozambique) with emphasis on Moçambique Island. Western Indian Ocean J Mar Sci 4:175-183

Mattio L, Bolton JJ, Anderson RJ (2015) Contribution to the revision of the genus Sargassum (Fucales, Phaeophyceae) in Madagascar using morphological and molecular data. Cryptogam Algol 36:143-169

McHugh DJ (2002) Prospects for seaweed production in developing countries. FAO Fisheries Circular No. 968 FIIU/C968.

Middle East Eye News (2015). (https://www.middleeasteye.net/news/ hard-times-red-gold-divers-moroccos-el-jadida). Accessed October 2020

Mirera DO, Kimathi A, Ngarari MM, Magondu EW, Wainaina M, Ototo A (2020) Societal and environmental impacts of seaweed farming in relation to rural development: the case of Kibuyuni village, south coast. Kenya Ocean Coast Manag 194:105253

Mollion J (2020) The seaweed resources of Madagascar. Bot Mar 63:97-104.

Mollion J, Razanakoto I, Ratsimba A (1996) Resources and possibilities exploitation in Madagascar for seaweed. Curr Trends Mar Bot Res East African Reg 218-222

Molloy FJ (1998) The seaweed resources of Namibia. In: Ohno M, and Critchley AT (eds) Seaweed resources of the world. Kanagawa International Fisheries Training Center, Japan International Cooperative Agency, Yokusaka

Molloy FJ, Bolton JJ (1995) Distribution, biomass and production of Gracilaria in Liideritz Bay, Namibia. J Appl Phycol 7:381-392

Morocco Seaweed Supplier- https://www.morocco-seaweed.com/graci laria/. Accessed May 2021

Moussa H, Hassoun M, Salhi G, Zbakh H, Riadi H (2018) Checklist of seaweeds of Al-Hoceima National Park of Morocco (Mediterranean Marine Protected Area). Acta Bot Malacitana 43:91-109.

Mshigeni KE (1973) Exploitation of seaweeds in Tanzania. The genus Eucheuma and other algae. Tanzania Notes and Records 72:19-36

Mshigeni KE (1992) Seaweed farming in Tanzania, a success story. In: Mshigeni KE, Bolton J, Critchley A. Kiangi G (eds.) Proceedings of the First International Workshop on Sustainable Seaweed Resource Development in Sub-Saharan Africa, Windhoek, Namibia, pp 221-245

Mshigeni KE, Jahn R (1995) Eucheuma (Rhodophyta, Gigartinales) in the W. Indian Ocean region - notes on collections kept in BerlinDahlem and Hamburg. Willdenowia 25:399-407

Mshigeni, KE, Semesi AK (1977) Studies on carrageenans from the economic red algal Genus Eucheuma in Tanzania. Bot Mar 20:239-42

Msuya FE (2006) The Seaweed Cluster Initiative in Zanzibar, Tanzania. In: Mwamila BLM,Temu AK (eds) Proceedings of the 3rd Regional Conference on Innovation Systems and Innovative Clusters in Africa, Dar es Salaam, Tanzania

Msuya FE (2010) Development of seaweed cultivation in Tanzania: the role of the University of Dar es Salaam and other institutions. Development 82:1-26

Msuya FE (2011a) Environmental changes and their impact on seaweed farming in Tanzania. World Aquac 42:71
Msuya FE (2011b) The impact of seaweed farming on the social and economic structure of seaweed farming communities in Zanzibar. Tanzania World Aquac 2011:60

Msuya FE (2013a) Social and economic dimensions of carrageenan seaweed farming. In: Valderrama D, Cai J, Hishamunda N, Ridler $\mathrm{N}$ (eds) eds. Social and economic dimensions of carrageenan seaweed farming, Fisheries and Aquaculture Technical Paper No. 580. FAO, Rome pp 115-146

Msuya FE (2013b) Effects of stocking density and additional nutrients on growth of the commercially farmed seaweeds Eucheuma denticulatum and Kappaphycus alvarezii in Zanzibar Tanzania. Tanzania J Nat Appl Sci 4:605-612

Msuya FE (2017) Technological development to help women seaweed farmers cope with the effects of climate change in Zanzibar, Tanzania. World Aquac 2017:45-47

Msuya FE (2020) Seaweed resources of Tanzania: status, potential species, challenges and development potentials. Bot Mar 63:371-380.

Msuya FE, Hurtado AQ (2017) The role of women in seaweed aquaculture in the Western Indian Ocean and South-East Asia. Eur J Phycol 52:482-494

Msuya FE, Neori A (2002) Ulva reticulata and Gracilaria crassa: macroalgae that can biofilter effluent from tidal fishponds in Tanzania. West Indian Ocean J Mar Sci 1:117-126

Msuya FE, Porter M (2014) Impact of environmental changes on farmed seaweed and farmers: the case of Songo Songo Island, Tanzania. J Appl Phycol 26:2135-2141

Msuya FE, Kyewalyanga MS, Bleicher-Lhonneur G, Lampin T, Lhonneur J-P, Mazoyer J, Critchley AT (2012) Seasonal variation in growth rates and carrageenan properties of Kappaphycus alvarezii and Eucheuma denticulatum cultivated with and without additional nutrients, in Uroa, Zanzibar, Tanzania. Tanzania J Nat Appl Sci 3:524-535

Msuya FE, Buriyo A, Omar I, Pascal B, Narrain K, Ravina JJM, Mrabu E, Wakibia JG (2014) Cultivation and utilisation of red seaweeds in the Western Indian Ocean (WIO) Region. J Appl Phycol 26:699-705

Muraguri EN, Wakibia JG, Kinyuru JN (2015) Chemical composition and functional properties of selected seaweeds from the Kenya Coast. J Food Res 5:114

Mwalugha HM, Wakibia JG, Kenji GM, Mwasaru MA (2015) Chemical composition of common seaweeds from the Kenya Coast. J Food Res 4:28

Mzibra A, Aasfar A, El Arroussi H, Khouloud M, Dhiba D, Meftah Kadmiri I, Bamouh A (2018) Polysaccharides extracted from Moroccan seaweed: a promising source of tomato plant growth promoters. J Appl Phycol 30:2953-2962

Neveux N, Bolton JJ, Bruhn A, Roberts DA, Ras M (2018) The bioremediation potential of seaweeds: recycling nitrogen, phosphorus, and other waste products. In: La Barre S, Bates SS (eds) Blue Biotechnology, Vol 1. Wiley, NY pp 217-239.

Nobre AM, Robertson-Andersson D, Neori A, Sankar K (2010) Ecological-economic assessment of aquaculture options: comparison between abalone monoculture and integrated multi-trophic aquaculture of abalone and seaweeds. Aquaculture 306:116-126

Northrop E, Konar M, Frost N, Hollaway E (2020) A sustainable and equitable blue recovery to the COVID-19 crisis. https://ocean panel.org/sites/default/files/2020-09/20_HLP_Report_COVID_ Blue_Recovery.pdf. Accessed May 2021

Noura H, Mohammed C, Mostapha C, Tojo N (2014) Study of the red algae growth Gracilaria multipartita (Clemente) Harvey (Rhodophyta, Gracilaria Les) of the Moroccan Atlantic coast. Int J Sci Res Publ 4:1-6

Odhiambo JO, Wakibia J, Sakwa MM (2020) Effects of monitoring and evaluation planning on implementation of poverty 
alleviation mariculture projects in the coast of Kenya. Mar Policy 119:104050

Ollando JA, Mwakumanya MA, Mindra B (2019) The viability of red alga ( Gracilaria salicornia) seaweed farming for commercial extraction of agar at Kibuyuni in Kwale county South Coast Kenya. Int J Fish Aquat Stud 7:175-180

Oyieke, HA (1998) The seaweed resources of Kenya. in: Critchley, AT, Ohno, M (eds). Seaweed Resources of the World. Japan International Cooperation Agency, Yokosuka, pp. 385-388

Pelegrin JL, Pena-Izquierdo J (2015) Eastern boundary currents off North - West Africa. In: Valdés L, Déniz-González I (eds) Oceanographic and biological features in the Canary Current Large Marine Ecosystem. IOCUNESCO, Paris. IOC Technical Series, No. 115, pp. 81-92. Accessed May 2021

Rahelivao MP, Gruner M, Andriamanantoanina H, Andriamihaja B, Bauer I, Knölker H-J (2015) Red algae (Rhodophyta) from the coast of Madagascar: preliminary bioactivity studies and isolation of natural products. Mar Drugs 13:4197-4216

Reis RP, das Chagas Pereira RR, de Góes HG (2015) The efficiency of tubular netting method of cultivation for Kappaphycus alvarezii (Rhodophyta, Gigartinales) on the southeastern Brazilian coast. J Appl Phycol 27:421-426.

Rhimou B, Hassane R, José M, Nathalie B (2010) The antibacterial potential of the seaweeds (Rhodophyceae) of the Strait of Gibraltar and the Mediterranean coast of Morocco. Afr J Biotechnol 9:6365-6372

Ribeiro, F (2007) Inventory of small-scale mariculture in Mozambique. WIOMSA SUCCESS Program. http://www.wiomariculture.org/ pubs/Mariculture\%20inventoty\%20Mazambique.pdf. Accessed May 2021

Robertson-Andersson D, Potgieter M, Hansen J, Bolton J, Troell M, Anderson R, Halling C, Probyn T (2008) Integrated seaweed cultivation on an abalone farm in South Africa. J Appl Phycol 20:579-595

Roque BM, Venegas M, Kinley RD, de Nys R, Duarte TL, Yang X, Kebreab E (2021) Red seaweed (Asparagopsis taxiformis) supplementation reduces enteric methane by over 80 percent in beef steers. PLoS ONE 16:e247820

Rotmann KWG (1987) The collection, utilization and potential farming of red seaweeds in Namibia. Hydrobiologia 151-152:301-305

Rothman M (2015) The phylogeny, biology and biogeography of the Southern African kelps Ecklonia maxima and Laminaria pallida. $\mathrm{PhD}$ Thesis, University of Cape Town

Rothman MD, Anderson RJ, Boothroyd CJT, Kemp FA, Bolton JJ (2009) The gracilarioids in South Africa: long-term monitoring of a declining resource. J Appl Phycol 21:47-53

Rothman MD, Bolton JJ, Stekoll MS, Boothroyd JT, Kemp FA, Anderson RJ (2017) Geographical variation in morphology of the two dominant kelp species, Ecklonia maxima and Laminaria pallida (Phaeophyceae, Laminariales), on the west coast of Southern Africa. J Appl Phycol 29:2627-2639

Rothman MD, Anderson RJ, Kandjengo L, Bolton JJ (2020) Trends in seaweed resource use and aquaculture in South Africa and Namibia over the last 30 years. Bot Mar 63:315-325.

Rull Lluch J (2002) Marine benthic algae of Namibia. Sci Mar 66:5-256.

Rusekwa SB, Campbell I, Msuya FE, Burijo AS, Cottier-Cook EJ (2020) Biosecurity policy and legislation of the seaweed aquaculture industry in Tanzania. J Appl Phycol 32:4411-4422

Sanchez-Jerez P, Karakassis I, Massa F et al (2016) Aquaculture's struggle for space: the need for coastal spatial planning and the potential benefits of Allocated Zones for Aquaculture (AZAs) to avoid conflict and promote sustainability. Aquac Environ Interact $8: 41-54$
Sánchez-Velásquez JJ, Reyes-Flores LE, Yzásiga-Barrera C, ZeladaMázmela E (2021) The introduction of the asian red algae $\mathrm{Mel}$ anothamnus japonicus (Harvey) Díaz-Tapia \& Maggs in Peru as a means to adopt management strategies to reduce invasive non-indigenous species. Diversity 13:176

Santos R, Melo RA (2018) Global shortage of technical agars: back to basics (resource management). J Appl Phycol 30:2463-2473

Segbefia AY, Barnes VR, Akpalu LA, Mensah M (2018) Environmental location assessment for seaweed cultivation in Ghana: a spatial multi-criteria approach. Int J Appl Geospatial Res 9:51-64

SELT MARINE GROUP (2021) https://www.submariner-network.eu/ images/grass/Seaweed_farming_and_industrial_processing.pdf). Accessed May 2021.

Semesi, AK (1979) Studies on industrial polysaccharides from selected Tanzanian marine algae. PhD Thesis, University of Dar es Salaam

Serfor-Armah Y, Nyarko BJ, Osae EK, Carboo D, Anim-Sampong S, Seku F (2001) Rhodophyta seaweed species as bioindicators for monitoring toxic element pollutants in the marine ecosystem of Ghana. Water Air Soil Pollut 127:243-253

Serfor-Armah Y, Carboo D, Akuamoah RK, Chatt A (2006) Determination of selected elements in red, brown and green seaweed species for monitoring pollution in the coastal environment of Ghana. J Radioanalyt Nuclear Chem 269:711-718

Shuuluka D (2011) Ecophysiological studies of three south African Ulva species from integrated seaweed/abalone aquaculture and natural populations. $\mathrm{PhD}$ Thesis, University of Cape Town

Smetacek V, Zingone A (2013) Green and golden seaweed tides on the rise. Nature 504:84-88

Solarin BB, Bolaji DA, Fakayode OS, Akinnigbagbe RO (2014) Impacts of an invasive seaweed Sargassum hystrix var. fluitans (Børgesen 1914) on the fisheries and other economic implications for the Nigerian coastal waters. IOSR J Agric Vet Sci 7:01-06

Stegenga H, Bolton JJ, Anderson RJ (1997) Seaweeds of the South African west coast. Contributions from the Bolus Herbarium 18. $655 \mathrm{pp}$

Steyn PP (2009) The ecophysiology of Gelidium pristoides (Turner) Kuetzing: towards commercial cultivation. PhD Thesis, Nelson Mandela Metropolitan University

The Seaweed Company-unpublished online information. https://www. theseaweedcompany.com/. Accessed May 2021

Valderrama D, Cai J, Hishamunda N, Ridler N, Neish IC, Hurtado AQ, Narayanakumar R, Kronen M, Robledo D, Gasca-Leyva E, Fraga J (2015) The economics of Kappaphycus seaweed cultivation in developing countries: a comparative analysis of farming systems. Aquac Econ Manag 19:251-277

Vieira C, De Ramon NA, Rasoamanendrika FA, D'Hondt S, Tran L-AT, Van den Spiegel D, Kawai H, De Clerck O (2021) Marine macroalgal biodiversity of northern Madagascar: morpho-genetic systematics and implications of anthropic impacts for conservation. Biodivers Conserv 30:1501-1546

Wakibia JG, Anderson RJ, Keats DW (2001) Growth rates and agar properties of three gracilarioids in suspended open-water cultivation in St. Helena Bay. South Africa J Appl Phycol 13:195-207

Wakibia JG, Bolton JJ, Keats DW, Raitt LM (2006) Factors influencing the growth rates of three commercial eucheumoids at coastal sites in southern Kenya. J Appl Phycol 18:565-573

Wakibia JG, Ochiewo J, Bolton JJ (2011) Economic analysis of eucheumoid algae farming in Kenya. West Indian Ocean J Mar Sci $10: 13-24$ 
Yaich H, Garna H, Besbes S, Paquot M, Blecker C, Attia H (2011) Chemical composition and functional properties of Ulva lactuca seaweed collected in Tunisia. Food Chem 128:895-901

Yarish C, Wamukoya G (1990) Seaweeds of potential economic importance in Kenya: field survey and future prospects. Hydrobiologia 204-205:339-346
Publisher's note Springer Nature remains neutral with regard to jurisdictional claims in published maps and institutional affiliations. 